\title{
The remaking of a high school reader
}

\author{
Lesley A. Rex \\ University of Michigan, Ann Arbor, USA
}

A

critical issue in English language arts education at the secondary level is how to successfully integrate students who have been ability tracked (e.g., as Remedial, Basic English, English Second Language, General English, or Resource) into classrooms with more demanding academic expectations. These courses challenge students' accustomed views of their roles as students and of what constitutes literate performance. One way of viewing their challenge is to think of it as reshaping a new identity: a new way of acting as, and consequently of being and being seen as a reader, a writer, and a speaker (Gee, 1996). For lower or marginaltrack students to successfully integrate into classrooms with academic capital, they need to remake themselves within classroom conditions conducive to integration.

That readers are made through the sociolinguistic discourse practices of the classroom speech communities in which they live has been extensively theorized and explored in prior analyses of classroom discourse (e.g., Cook-Gumperz \& Gumperz; 1992; Green \& Meyer, 1991). How remaking occurs in classrooms has been given far less attention. In fact, research has documented how infrequently students move from one academic identity to another (Oakes, 1985). This study, through microanalysis of ethnographically obtained classroom discourse data, describes how remakings successfully occurred in one classroom in which general readers were remade as gifted and talented readers. These labels used by the school's students and teachers represent a cultural way of identifying student readers, a way that had been socially constructed and maintained and that could be socially reconstructed or transformed.

Transformation of student identities and conditions supportive of transformation will be represented in this study through illustrations of (a) a general student's emergent reading practices, (b) her classroom's collective discursive resources, and (c) her teacher's shifting pedagogical role and actions as students became more competent, transformed readers. These illustrations provide a snapshot, an angle of vision, into the transitory, dynamic, interrelated, historical complexity of the interactions between students and teachers that constitute classroom teaching and learning. Acknowledging that an illustrative representation is always incomplete and always from a perspective (Green, Franquiz, \& Dixon, 1997; Ochs, 1979), I selected the three illustrations from extensive data sources in respective response to three questions: Who or what is a general student becoming? When do we mark the performance moments that describe transformation? and What data points can be explored to describe the nature of the transformation?

The snapshot represents a student we'll call Kora and her reading performances in relation to her classrooms' discursive resources and to her teacher's key actions during classroom discussions. This article forwards a view of transformation of reader identity as the accumulative effect of occasions when an individual's reading performance met the evolving expectations of the collective. This angle of vision circumscribes a particular view of multiple relationships between the collective conditions facilitating transformation and individual transformation. It assumes that a classroom's activity builds and transforms in relationship to members' participation; and members' performances emerge and transform in relation to evolving literacy teaching and learning activities and, their meaning for the members. The snapshot will make it possible to theorize about the importance of orientation in the local reconstruction of institutionalized student 


\section{The remaking of a high school reader}

There is ample evidence that students frequently move unsuccessfully from a lower to a higher academic track, but little research into how students successfully make that transition. This investigation builds on scholarship in literacy and teaching and learning suggesting that to be successful, students' identities as readers, writers, and speakers need to be remade within classrooms whose practices are conducive to integration. This study analyzes ethnographically collected classroom discussions and student work to provide telling cases of the conditions that support the remaking of a reader. Focusing on a classroom that positioned general students to engage discursively like gifted and talented students, the study describes a general student's emergent gifted and talented reading practices, the classroom's collective discursive resources, and the teacher's shifting pedagogical role and actions as readings and student identities were undergoing reconstruction. The case analyses illustrate the central relationship between individual readers and their membership in a reading culture they are coconstructing. They demonstrate the importance of orientation in students' and teachers' construction of what constitutes membership. In doing so, the analyses illuminate a concept of reading and of being a reader, and a method for studying it, that is sociocultural.

\section{La Reconstrucción de un Lector de Escuela Secundaria}

Existe amplia evidencia sobre el hecho de que los estudiantes frecuentemente pasan poco satisfactoriamente de un nivel académico a otro superior, pero escasa investigación acerca de cómo los estudiantes hacen esa transición en forma satisfactoria. Esta investigación se basa en los conocimientos sobre alfabetización, ense anza y aprendizaje y sugiere que para ser exitosas, las identidades de los estudiantes como lectores, escritores y hablantes deben ser reconstruídas en aulas en las que las prácticas resulten en la integración. Este estudio analiza etnográficamente una recolección de discusiones en el aula y el trabajo de los estudiantes para proporcionar casos de las condiciones que sustentan la reconstrucción de un lector. Poniendo el foco en un aula que ubicaba a los estudiantes en la

\section{Die Neuschaffung eines Lesers in der Oberschule}

Es gibt genügend Belege, daß Schüler häufig erfolglos von einer unteren Bildungsstufe in eine höhere wechseln, jedoch wenig Erforschung darüber, wie Schüler den Übergang mit Erfolg ausführen. Diese Untersuchung baut auf Stipendien im Schreiben und Lesen und im Lehren und Lernen, indem sie empfiehlt, daß, um erfolgreich zu sein, die Schüleridentitäten als Leser, Schreiber und Sprecher innerhalb von Klassenräumen geschaffen werden müssen, deren Praktiken integrationsfördernd sind. Diese Studie analysiert ethnographisch gesammelte Klassenraumdiskussionen und Schülerarbeiten, um nennenswerte Fälle zu liefern, welche jene Bedingungen aufzeigen, die die Neuschaffung eines Lesers unterstützen. Mit Hinblick auf einen Klassenraum, der allgemein-durchschnittliche Schüler dazu in die Lage versetzte, sich im Verlauf diskursiv wie be- posición de participar discursivamente como estudiantes dotados y talentosos, el estudio describe las prácticas emergentes de lectura dotadas y talentosas de un estudiante, los recursos discursivos colectivos del aula y el rol y las acciones pedagógicas del docente que se adaptaban al proceso de reconstrucción de las lecturas e identidades del estudiante. El análisis de caso ilustra la relación central entre los lectores individuales y su pertenencia a la cultura lectora que están co-construyendo. Demuestran la importancia de la orientación en la construcción por parte de estudiantes y docentes de lo que constituye la pertenencia. De este modo, el análisis ilumina un concepto de la lectura y de ser lector, así como un método para estudiarlo, que es sociocultural. gabte und talentierte Schüler einzusetzen, beschreibt die Studie das Aufsteigen eines allgemein-durchschnittlichen Schülers hin zu begabten und talentierten Lesepraktiken, die kollektiv-diskursiven Kräfte des Klassenraumes, und die sich wandelnde pädagogische Rolle des Lehrers, und Maßnahmen im Verlauf von sich neugestaltenden Leseleistungen und Schüleridentitäten. Die Fallanalysen illustrieren die zentrale Beziehung zwischen den individuellen Lesern und ihrer Mitgliedschaft in der Lesepflege, welche sie mitgestalten. Sie zeigen die Bedeutung bei der Orientierung in der Konstruktion von Schülern und Lehrern von dem, was sich als Mitgliedschaft konstituiert. Von daher beleuchten die Analysen ein Konzept des Lesens und des Leserbewußtseins, und einer Methode, dies zu studieren, welche sozio-kulturell ist. 


\section{ハイスクールの読者の再構成}

成績の上がらない生徒についての例はたくさんある のに、成績を上げた生徒についての研究はほとんど ない。この研究は、成績を上げた生徒の、読み手、 書き手、話し手としてのアイデンティティーはそれ らの能力が偏らずに練習ができる教室のなかで、再 構成されるべきとする教授学習法を前提としている。 この研究では、どのような条件が再構成を促すかを 示すケースを提供するような、観察を通して集めら れた教室内のディスカッションや生徒の作業が分析 される。この研究は、普通の生徒を才能のある生徒 であると推測的に保証するべく配置する教室に焦点 をあて、普通の生徒が急速に読書実践の能力を身に

\section{La réfection d'un lecteur de collège}

Il est bien connu que des élèves passent souvent d'un niveau scolaire à un autre sans davantage réussir, mais peu de recherches montrent comment certains élèves parviennent toutefois à réussir ce passage. Notre investigation, qui repose sur la littératie à l'école, l'enseignement et l'apprentissage, suggère que, pour être un élève qui réussisse, il faut refaire son identité en tant que lecteur, scripteur et parleur dans des classes dont les pratiques conduisent à une intégration. Cette étude est une analyse ethnographique de discussions enregistrées en classe et de travaux d'élèves, en vue de définir quelles sont les conditions qui permettent la réfection d'un lecteur. En se centrant sur une classe qui amène des élèves en général à s'engager de façon discursive, comme le font des élèves doués et

\section{Перевоспитание читателя-старшеклассника}

С возрастом дети начинают учиться хуже, и свидетельств тому множество, но случаи успешного перехода на более высокий академический уровень исследованы мало. Мы сосредоточились на аспекте чтение/письмо в обучении, поскольку предположили, что успешные читатели, авторы и докладчики формируются на уроках, благоприятных для интеграции. Проанализирован этнографический материал - записи учебных дискуссий и ученические работы, - собранный для оценки условий, способствуюших перевоспитанию читателя. Основное внимание уделено занятиям, на которых обычным, заурядным учащимся предложено принять участие в дискурсивном анализе, и описано, какими одаренными
つけたこと、教室の集合的な推論的な資料、及び教 師の変わりやすい教育学的な役割と読書という行為 と生徒のアイデンティティーが再構成されたことを 記述する。この事例分析により、個々の読者と彼ら が共同で構成している読書環境への彼らのメンバー シップとの中心的な関保が解明される。それらの分 析は、メンバーシップを構成するものを生徒や教師 がどのように作り上げているのかがいかに重要かを 示している。そうすることで、その分析は、読書と は何か、読者であるとはどんなことなのか、またそ れを研究する社会文化的方法がどのようなものかを 解明している。

talentueux, l'étude décrit pour un élève en général les pratiques émergentes de lecture d'élèves doués et talentueux, les ressources discursives collectives de la classe, ainsi que le changement de rôle pédagogique du maître et de ses interventions, lorsque la lecture et l'identité des élèves sont en cours de reconstruction. Les analyses de cas illustrent la relation centrale entre des lecteurs individuels et leur appartenance à une culture de la lecture quils co-construisent. Ils montrent l'importance de l'orientation de la construction par les élèves et les maitres de ce qui constitue cette appartenance. Ce faisant, l'analyse clarifie une conception de la lecture et de ce que c'est qu'être un lecteur, ainsi qu'une méthode pour en faire l'étude, qui est socioculturelle.

и талантливыми читатслями они предстают в итоге, какие неисчерпаемые дискурсивные ресурсы открываются на уроках и как меняется педагогическая роль и действия учителя по мере того, как меняется чтение ученика и его личность. Анализ показывает, что определяющим параметром успешности является отношение отдельных читателей к себе как к представителям создаваемой ими читательской культуры. И учашимся, и учителям важно дать понять, что такое "член сообщества". Настоящий анализ высвечивает такие понятия, как чтение и читатель, а также демонстрирует метод их изучения, т.е. социокультурный метод. 
identities, like gifted and talented, and of the teaching and learning practices that constitute reconstruction. It will illuminate a concept of reading and a method for studying the remaking of a reader in terms of becoming a member of a reading socioculture.

\section{Related research}

The assumption that classroom discourse practices remake as well as make students as literate performers builds on previous work such as Cochran-Smith's (1984) ethnographic study of the way adults socialized preschool children into particular patterns of school literacy different from their community literacies. Cochran-Smith's analysis of teacher-child interaction during storybook reading described how, through key activities and discourse moves, student readers were remade within and across multiple layers of meaningful contexts through a process of gradual socialization, rather than through direct teaching. These contexts included (a) an interactional orientation, supported by a particular behavioral and physical participation structure called rug time; (b) other off-the-rug activities calling for rug time-like reading; (c) a general environment that organized time, space, activity, and interactional norms consistent with this approach to reading; and (d) adults who valued it.

In addition to Cochran-Smith's work, this article is informed by another exploring the centrality of discourse in the construction of classroom life and school literacy (Hicks, 1995; 1996). Kantor, Green, Bradley, and Lin (1992) explored preschool circle time as a speech event key to building certain rules for social participation and school performance. Circle-time analysis described how particular ways of communicating and interacting in classroom instructional events related to how activity was accomplished, what was available to be learned, and what was actually learned. The analysis illustrated how student participation within classrooms led them to construct particular discourse repertoires for accessing academic content. Most important to this study were analyses of class members' interactions across time and how patterns of interaction and relationship shifted, forming collective norms for what it meant to talk in a group and talk as a group. These analyses illustrated the transient, transformative, and consequential nature of literate discourse construction.

Other researchers' studies of classroom readershaping processes at later stages of schooling offer views of students and teachers engaged in transformative processes. Studies of middle school classrooms have shown how the situated practices of particular English classrooms shaped what it meant to be a reader in those classrooms (Bloome, 1989; Lin, 1993). Studies describe how high school readers were positioned and positioned themselves as readers in classrooms through multiple roles and relationships with their teacher and subject matter (Prentiss, 1998; Rex, 1994; Rex \& McEachen, 1999). Scholars describe ways in which what counts as reading is under continual historical and local reconstitution and thus is always a situated practice (Green \& Meyer, 1991; Heap, 1991), and that readings in a classroom are continually and actively reconstituting the subject matter of reading (e.g., Baker \& Luke, 1991; McHoul, 1991; Santa Barbara Classroom Discourse Group, 1992a).

\section{Conceptual frame}

To make visible how students are reshaped as readers calls for a view of teaching and learning that represents the individual learner in relation to the classroom collective as a member of an evolving, emergent reading culture. Such a perspective makes it possible to describe interactive relationships between student social identity, knowledge construction, and group expectations for performance. In this section, I explain the conceptual facets of this perspective.

This view regards teacher and student not as states of being, but rather as roles that members of a classroom take up (and exchange) to suit particular occasions (Santa Barbara Classroom Discourse Group, 1992b). Therefore, teaching and learning become the joint activity of individual classroom members as they collectively construct what counts as the content and procedures of learning. From this perspective, the discursive actions of members in the role of teacher are regarded as mediational (JohnSteiner, Panofsky, \& Smith, 1994). Teachers, through their spoken and written actions, serve as mediators in the joint construction of collective academic knowledge (e.g., academic reading practices, procedures, and subject matter) and of social knowledge (e.g., social roles and relationships and attendant rules for social participation).

Students (i.e., learners), as they interact with teachers (i.e., mediators) in the literacy learning culture of the classroom, are shaped by it. As they construct readings and writings about readings and engage in their assessment, they are reconstructed as particular kinds of students by the social identity the process calls for (Fairclough, 1993), as though they had taken on an identity kit (Gee, 1996). Students position themselves or step into particular social and academic roles as readers, and they are positioned or "made to seem a certain type of person" (or reader) by their classmates' responses (Ivanic, 1994, p. 4).

Bakhtin's (1981, 1986) sociohistorical conceptualization of voice, interaction, and understanding provides a basis for viewing how individual learning and identity formation occur in the linkage between local, in-the-mo- 
ment interactions of individuals and historical, over-time discourse activity of the collective. Identity construction, seen as the positioning of the speaker in current social and cultural relationships through discourse moves, occurs by way of and is observable in students' voicings. A voicing is a speaking personality, a speaking consciousness that arises out of the speaker's history with the current classroom social group and with previous social experiences in other classrooms. Speakers have more than one voice, and they exercise particular voices depending upon the speaking situation.

For example, in this classroom when student Kora made an incorrect public reading of a phrase in Chaucer's "Priest's Tale" (in Coghill, 1977), she confessed that she needed help in getting through the complicated Christian analogies. Kora could voice distress and need for assistance because she understood that in this situation help was available, warranted, and expected to be given. Her teacher and classmates, who acknowledged her difficulty, came to her rescue to provide information and to save her social face. The voices they brought forward suited the situation while they constructed a reading. Theirs and any new dialogue about reading may be understood, in part, as cosubstantiating or bringing into concrete coexistence historically established voices within the current space, time, and social conditions. Students recall and reconstruct old voices and construct new ones as their readings of current speaking situations warrant (Bakhtin, 1981, 1986). Furthermore, the voices students feel comfortable using in a current classroom situation will influence the voices they will employ during reading events later in that classroom and in others.

Bakhtin's notions of voice and dialogue tie identity building to knowledge building or learning. He conceives of knowledge as historically constructed, ideological, cultural texts, the knowing of which is visible in spoken and written utterances. Utterances are the textual or linguistic manifestations of speakers' voices, and they take on meaning as speakers engage in dialogues with one another.

Within these dialogues, in the exercise of voice through utterance, speakers bring new understanding or knowledge into existence. Knowledge is what knowers understand as a phenomenon (Bakhtin, as cited in Todorov, 1984). To apply this concept to reading, we could say that as a reader Kora is a knower of what she has come to understand as reading within the social relationships of former reading situations. That is, what she understands as reading exists in her historical personal relationship with particular ways of reading and with other readers, and in her own stake in the knowing. To say one understands how to read is to say (often without conscious awareness) one values, remembers, believes, and wants the knowledge of reading one has or is building. Reading knowledge is, then, always constructed through dialogues between speakers who build on and reconstruct what they value as the personal, social, and historical stake they have in reading. For teachers to offer opportunities for new reading knowledge to be built, there must be opportunities for new understanding to occur, and teachers must recognize them as opportunities, as must their students. For students to make new understandings they must regard them as personally, socially, and historically valuable.

In a classroom such as the site for this study, in which some members are more experienced readers in the manner expected by the teacher (i.e., the gifted and talented students), the construct of complementarity is useful. John-Steiner and Mahn (1996) used complementarity to argue that joint activity creates the potential for more and less experienced learners to learn and transform together. Less experienced learners rely on the more experienced to accomplish what would require more time alone; the more experienced are transformed by the challenge and the social energy, and by reexperiencing the reading activity in new ways (Putney, Green, Dixon, Duran, \& Yeager, 2000).

Individual valuing and complementarity in teaching and learning exist within social and cultural power relations in classrooms (Fairclough, 1989). The value given to the ways general students read compared to gifted and talented students' ways of reading (and the consequent value ascribed to the students themselves) is related to teachers' belief in the respective value of the reading practices. The more valued a way of reading, the more access is given to the student to exercise it, and the more status accrues to the user. To some extent in all classrooms (and intentionally within the classroom of this study) each interaction expresses and builds a context of power relations between the students and their teacher. Thereby, each classroom is an expression of and contributes to a school culture that privileges some speakers or readers and ways of speaking or reading above others (Lankshear \& McLaren, 1993). Teachers play a pivotal role in mediating which way of reading and of being a reader will be privileged in each classroom and, thus, across classrooms and students' school reading experiences.

Noteworthy for this study is that general and gifted and talented students learn different ways of reading related to their assigned academic track (Oakes, 1985), "one stressing thinking for oneself and suited to higher positions in the social hierarchy and one stressing deference and suited for lower positions" (Gee, 1996, p. 35). A realignment of these disparate, inequitable understandings and identities requires a renegotiation of power by reconstituting in the classroom both the general and the gifted and talented students' knowledge about reading and one another. The teacher needs to mediate that 
negotiation by providing opportunities for reconstruction that disperse rather than reinforce extant power relationships between teacher and students and students (in the role of teacher) and students. This is achieved through classroom dialogue that locally constructs new positionings- that is, new norms for who can speak to whom and when-by establishing new rules for meaning and conduct (Lankshear \& McLaren, 1993).

Consequently, key to individual learning and remaking as a reader is becoming a contextually (i.e., a culturally) appropriate speaker (or writer) during moments of reading activity (Green \& Harker, 1982) and over multiple moments throughout related literate activity (Alton-Lee \& Nuthall, 1992). Other studies have provided views of how such literacy learning occurs. Weade's (1992) study of a program for gifted learners redefined the teachable moment of classroom learning as multiple moments of teaching, in which teaching and learning processes are interactive, recursive, and embedded rather than discrete and unidirectional. Alton-Lee and Nuthall (1992) found students need a critical mass of numbers of opportunities for learning, and teachers' skill is pivotal in providing opportunities recognized as appropriate by students. Researchers have expanded the concept of opportunities for learning by noting that opportunity is defined contingently over time by different subgroups at work within the classroom and by different teacher-group interactions, even when the instructional task is the same (Tuyay, Jennings, \& Dixon, 1995; Wells \& Chang-Wells, 1992). An opportunity for learning is recognizable only locally and in retrospect when students are observed taking up or acting upon the opportunity provided in a way meaningful to them and to the rest of the class (Edwards \& Mercer, 1987).

In summary, the remaking of a reader occurs through joint activity around common texts that provides prolific, contingent, dispersed, and open-ended opportunities for dialogue. Coconstructive remaking is characterized by constant shifting of student and teacher roles, power relations, voices, and understandings that are themselves in continual flux and intercontingent. With dialogue as the medium of these dynamics, what people say to one another becomes the medium, the means, and the common record of reader identity and knowledge. How the teacher mediates the dialogues over time is key to successful remaking.

\section{Method}

\section{The site}

The school was one of three U.S. high schools in a district of approximately 180,000 inhabitants. Beginning in the early 1980s, the demographics of the area shifted dra- matically, as did the transience of the population. Increasing desirability of the land and escalating land values resulted in a polarized shift in population to those who could afford to live there and those whose work was tied to these residents. A substantial increase occurred in the numbers of students from families below the poverty line for whom English was a second language. During the year of the study, the district identified $55 \%$ or 1,126 of the school's 1,950 students as members of ethnic minority groups, mostly Hispanic, and 440 students or $22 \%$ as Limited English Proficient. The students who entered the school came from junior high and middle schools in which $50 \%$ to $75 \%$ of students qualified for free or reducedcost lunch under Aid to Families With Dependent Children guidelines.

The school's academic tracking system conformed to these demographics. Students were sorted into Special Education, English Second Language (ESL), College Preparatory, and Gifted and Talented (GATE). It was not unusual for students to be given one of these institutional identities as early as kindergarten. They were GATE identified through three methods (usually at the urging of the student or the student's parents): appropriate GATE examination score, teacher nomination, or demonstration of exceptional talent such as winning a poetry competition. General students were college prep students by default. Little permeability existed across tracks. Once identified, students tended to be sorted into designated classes for the duration of their schooling.

\section{The teacher}

At the time of the study, the teacher had taught English for 30 years, the last 15 at this high school. A European American with an M.A. in English, he was the only English teacher qualified to teach Advanced Placement (AP) English for community college credit. Each term, in addition to GATE and General English classes, he also taught Basic Skills, a remedial course for the 9th-12th-grade students who had failed the high school English competency exam required for graduation, and who were mostly English Second Language students. The teacher was a 13-year fellow of his local writing and literacy project, an affiliate of the National Writing Project. He had served on district-wide committees to align the high schools' English curriculum, tutored privately, and conducted workshops in preparation for the Scholastic Assessment Test.

\section{The readers who entered GATE English literature}

The English literature classroom in the study was designated for students institutionally labeled "gifted and talented" (i.e., referred to by the acronym GATE). (Throughout the article I refer to students as they were 
labeled by their schoolmates and teachers to replicate the essentializing effect of their use of these terms.) However, school policy allowed all general English students to enroll in any GATE English class of their choosing. Ethnographic and institutional data indicate that this was a classroom stakeholders considered effective in preparing students who took the course for higher academic English experiences. Both GATE and general students went on to become successful English students in advanced English classes and at universities. The particular year of the study, of the 27 students who enrolled, 10 were general students and 17 were GATE. Of the 10 general students, 5 had previous experience in a GATE English classroom and 5 had none. Seventeen were female and 10 male. One female GATE student self-identified as Mexican American, 1 female general student as Mexican American, and the rest as European American. Kora, the general student in this study who had never taken a GATE English class, is a female of European descent who, after this study, took AP English and went on to graduate from the University of California.

Over the years, the students in this study became the kinds of readers their tracked school reading experiences shaped them to be. Although no unified, prescribed curricula or practices were taught consistently as GATE reading and non-GATE reading in this district, the two groups can be characterized as having two kinds of reading experiences in classrooms that shaped them as different kinds of readers.

GATE students were experienced readers of challenging texts. Class discussions and essay analyses of textual elements had been common practices in their classrooms where they were encouraged to think creatively and critically and base their readings upon textual evidence and reasoned argument. The general readers experienced shorter, less challenging texts and academic activity of briefer length requiring lower order retrieval and reporting of textual information. While GATE readers were inquirers, the general readers read to construct correct readings as demarcated by their teachers. For example, GATE students might discover, describe, and argue for how particular symbolic images played out in the actions of certain characters over the course of a novel; whereas general readers would demonstrate understanding of textual symbols by explaining the meanings of symbols identified by the teacher.

In addition, a hierarchic power structure-related to whose knowledge and questions counted and who had the right to bring their questions and knowledge forward for discussion - had an established history, which students carried into this classroom. Over the years, in this school as in others, GATE students had been socially instantiated as more proficient and knowledgeable academic readers whose privileged learning was granted privileged status. The subjectivities of GATE and general students had been formed within these hierarchies, such that Kora began her English literature experience with the belief that she was less intelligent, less capable, and less knowledgeable than her GATE classmates. Her GATE peers, assured of the rightness of their privileged knowing and being, assumed Kora's view of herself was correct.

\section{Reading in the GATE English literature classroom}

In this classroom students read lengthy canonical texts like Beowulf (Raffel, 1963) and Canterbury Tales (Coghill, 1977), and they wrote analytical essays requiring original interpretations and not those offered by the teacher. Following the classroom reading motto, "If anything is odd, inappropriate, confusing, or boring, it's probably important," they were to find places in the text they thought were "probably important." They were to figure out the probable importance of these pieces of text and make a case, or a reasoned reading supported by evidence from the text. Finally, they were to formulate a "so what" by embedding their reading into the whole structure of the text, into the world created by the text, or into readers' critical and historical understandings of the text. To make their cases, students had to conform to a particular logic. They formed a hypothesis that related their claim to a piece of evidence, and pieces of evidence to each other in a convincing chain. For example, if a student found a section that seemed inappropriate, he or she would generate a hypothesis as to why that might be. The hypothesis would have to be directly related to the specific section of troublesome text. Next, the student would formulate a claim (a thesis) in response to the hypothesis. This claim would have to be related to another piece of text that seemed to provide evidence for the claim. Next the reader would be required to find other pieces of related textual evidence with sufficient explanation of their relevance and arrange them in an order that built a persuasive case for the claim.

The motto provided a heuristic, a referential perspective (Wertsch, 1991), a place to stand from which readers could organize their thinking as they read or wrote a text. For instance, when a section struck them as inappropriate within the context of the text, the world of the text, or their discussions of the text, they should assume that it would probably be a potentially rich source about which to hypothesize, search for evidence, make a claim, and provide textual support. Table 1 provides a section of the argument the teacher made to the class as to why readers should "invest enough energy into these tricky little places so we can find out what's going on." 
Table 1 Teacher explains the class motto (represented in message units)

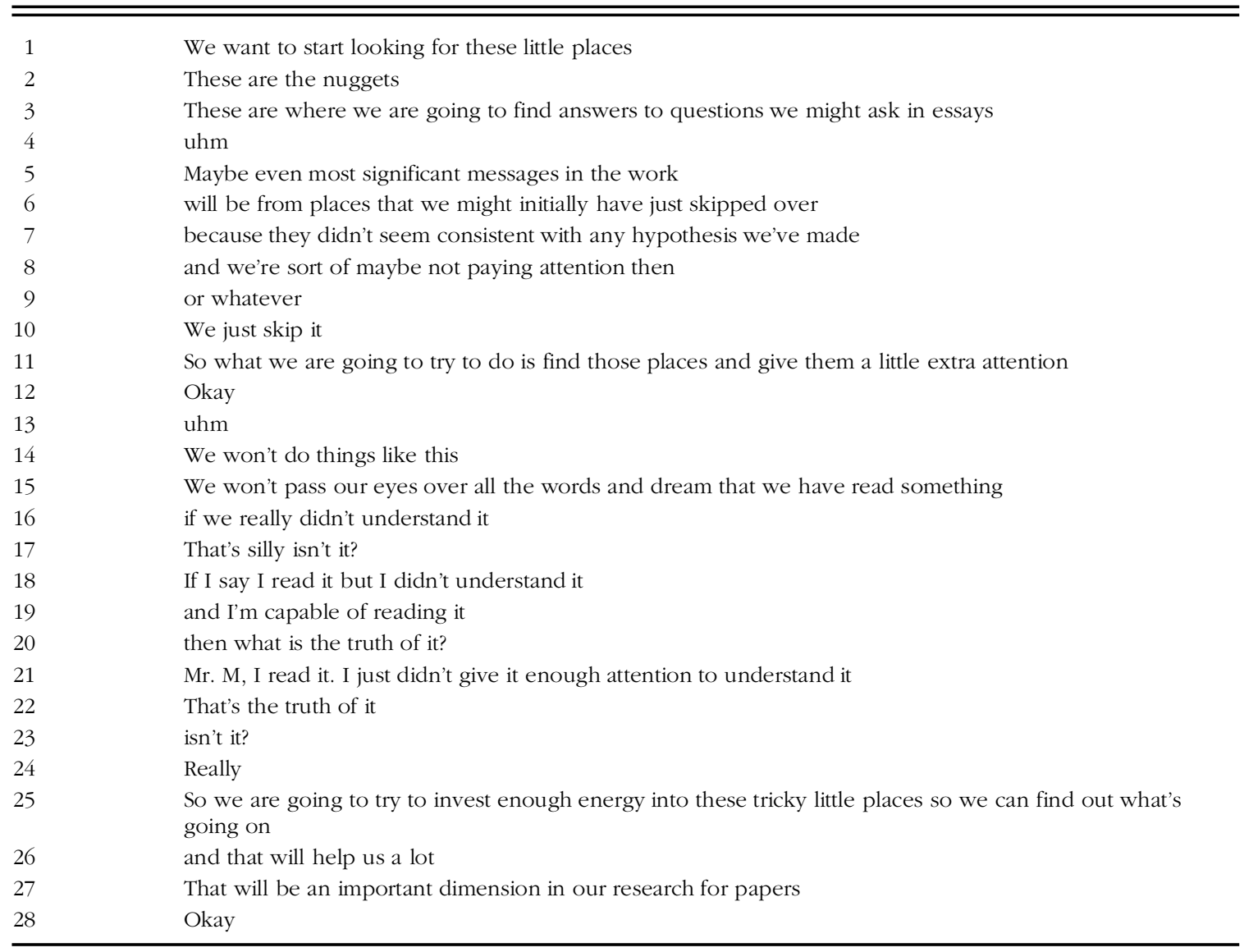

\section{Role of the researcher}

Up until launching the formal study, I had observed classrooms of all the English teachers in this high school for 7 years as part of my responsibilities as an English teacher educator at the local university. These observations represented nearly all of the English courses offered to students across all tracked levels from Advanced Placement to Basic Skills. Also, each year the teacher in the study and I had supervised student teachers in his classroom. I approached him about doing a formal study of his classroom's literacy practices as a joint research project with reciprocal benefits. The study served his interest in investigating the efficacy of his teaching methods and my concern with secondary literacy instruction.

\section{Data collection and analysis}

The year of the study, as an ethnographer I observed and participated in each of the first 31 classes of year-long GATE English literature, videotaping and interviewing with two cameras and multiple microphones. I also kept field notes and collected all teacher or student written artifacts, which included notes students wrote to me on logs, drafts, and surveys. The remainder of the school year, I met regularly with the teacher and reentered the classroom most weeks to gather data or to share data transcriptions and analyses with the whole class and with individual students. Their responses shaped further collection and analysis. Following methods developed by sociolinguists (e.g., Gumperz, 1992), classroom literacy researchers (e.g., Bloome \& Bailey, 1992; Green \& Wallat, 1981; Kantor, Green, Bradley, \& Lin, 1992), and cognitive anthropologists (e.g., Spradley, 1979, 1980), I transcribed (Ochs, 1979) and analyzed all the classroom's teaching and learning activity as discourse events in relation to other ethnographically collected data.

From this corpus of data, I selected for analysis particular classroom data points to serve as telling cases (Mitchell, 1983, 1984), which means they functioned heuristically to stimulate generalizations and induce theoretical interpretations about contextual circumstances. 
Ethnographic telling-case analysis permits the observer "to show how general regularities exist precisely when specific contextual circumstances are taken account of" (Mitchell, 1984, p. 239). For example, of the three cases selected for this study, the first, Kora's growth across her early reading quizzes, was a useful telling case to explore how her reading performance emerged within the collective reading resources of the classroom.

Telling cases became visible toward the end of a protracted part-whole, constant comparative process of question-driven data collection, analysis, and theorization (e.g., Erickson, 1986; Glaser \& Strauss, 1967), which can be characterized in two phases. The first phase was initiated by asking of the data, "What counts as providing opportunities for learning academic literacies and as taking up opportunities for learning academic literacies in this classroom?" Subsequent related questions asked, for example, "Which academic literacies are available to learn?" "Which members take up which literacies?" and "Which members provide opportunities for learning academic literacies?" (see Table 2). These questions made visible (a) patterned ways of reading, writing, and speaking; (b) norms for procedures and relationships; and (c) routinized teaching and learning practices, which served as collective resources for individual academic and social performance. That they were resources is based on the fundamental ethnographic assumption that classrooms are cultures in which members participate in ways meaningful to them that signal who can say or do what with whom, when, where, how, under what conditions, for what purposes, and with what outcomes (Zaharlick \& Green, 1991).

From the representations generated in the first phase, telling cases were selected for further analysis in a second phase. These were (a) a single way of reading (i.e., making a case), (b) an individual reader (i.e., emergent reader Kora), and (c) a particular occasion of teacher pedagogy (i.e., shifting instructional discourse in response to students' emergent reading proficiency). During analysis of the cases, questions were asked to elicit rich descriptions of interactive, part-whole relationships between collective resources and individual teaching and learning performances. For example, questions guiding the analysis of making-a-case reading practices were as follows: What is the making-a-case literacy? Where, when, and how was making a case constructed? What patterns of activity were opportunistic for making-a-

Table 2 Questions guiding data collection and phase one transcription and analysis

\begin{tabular}{|c|c|}
\hline \multicolumn{2}{|c|}{$\begin{array}{l}\text { What counts as providing opportunities for learning academic literacies and as taking up opportunities for learning academ } \\
\text { literacies in this classroom? }\end{array}$} \\
\hline Who? & $\begin{array}{l}\text { Which members provide opportunities for learning academic literacies? } \\
\text { Which members are provided with opportunities? } \\
\text { Which members take up opportunities? }\end{array}$ \\
\hline What? & Which academic literacies are available to learn? \\
\hline With whom? & Who are the interactional partners with whom the members will be learning? \\
\hline When? & $\begin{array}{l}\text { On what occasions, with what frequency, and in what timely fashion do teaching and learning } \\
\text { opportunities occur? }\end{array}$ \\
\hline Where? & $\begin{array}{l}\text { In which interactional spaces? } \\
\text { In what physical spaces? }\end{array}$ \\
\hline How? & $\begin{array}{l}\text { How are learning opportunities provided? } \\
\text { How are they taken up? } \\
\text { How are the literacies constructed? }\end{array}$ \\
\hline $\begin{array}{l}\text { Under what } \\
\text { conditions? }\end{array}$ & $\begin{array}{l}\text { In which social and power relationships are literacy practices constructed? } \\
\text { With what material resources? } \\
\text { With what social resources? } \\
\text { With what cultural resources? }\end{array}$ \\
\hline $\begin{array}{l}\text { For what } \\
\text { purposes? }\end{array}$ & $\begin{array}{l}\text { What are the goals and expectations for performance of the classroom members, the dominant members, } \\
\text { divergent members, and individual members? }\end{array}$ \\
\hline $\begin{array}{l}\text { With what } \\
\text { outcomes? }\end{array}$ & $\begin{array}{l}\text { What performances count? } \\
\text { How are they assessed and valued? } \\
\text { How is capability determined? }\end{array}$ \\
\hline
\end{tabular}


case literacy construction in this classroom? When and how did the teacher provide opportunities for a particular making-a-case activity to be taken up? How through his discourse actions with the class as a group did the teacher provide opportunities for students new to a making-a-case way of reading to become recognized as capable members? What particular kinds of learning opportunities did particular kinds of students recognize and take up, and in what ways? The collective resources described in relation to individual performances were, for example, cycles of reading-related activity, interactional spaces, routinized teaching and learning practices and their rules for participation and performance, and patterns of classroom reading discussion discourse.

This type of analysis was made possible by complementary theoretical assumptions about the fundamental role of group discourse practices in constituting relationships between a group's collective educational resources and individual performances. They are as follows:

- Each cultural group has a unique knowledge system for organizing and perceiving its world.

- Most of a group's cultural knowledge is reflected in the semantic relationships signaled by its language (Erickson, 1977; Hymes, 1972).

- This knowledge is organized into categories that are systematically linked (Spradley, 1979).

- Semantic analyses of a group's language describe the organizing principles of meaning within that culture and how they play out as norms for appropriate action (Geertz, 1973; Goodenough, 1981).

- Discourse between interactants in a culture is symbolic interaction steeped in meaningful social understandings of how to proceed even as it is transforming those understandings (Baker, 1991; Heap, 1991; Santa Barbara Classroom Discourse Group, 1992b ).

- Chains of interactional sequences that classroom members produce and regard as temporally, topically, and purposefully bound are cultural discourse events (Bloome \& Bailey, 1992; Green \& Meyer, 1991; Lin, 1993).

- They are meaningfully interpretable only within and across situations of social occurrence (Bloome \& Egan-Robertson, 1993).

- Multiple transcriptions (Ochs, 1979) of a classroom's discourse texts can provide alternative meaningful readings of teaching and learning events and their significance within the culture (Green \& Harker, 1982).

\section{Data transcription}

Discourse data were transcribed to represent the flow of classroom life as teaching and learning events (Bloome \& Bailey, 1992). An event is a basic unit of time, space, and activity as recognized by the members of the class. Single events, such as a Beowulf quiz and discussion, were represented in various transcriptions as composed of subevents, phases, and sequences of discourse. This system allowed the analyst to both locate a telling case within a particular context and explore part-whole relationships between them. The value of this embedded transcription approach lies in its ability to display relationships between single utterances and broader patterns and themes of classroom practices. These relationships may be represented, among other ways, in terms of time, participants, and social norms. For example, the relationships of time and space were transcribed for a specific interaction you will observe later, when the teacher redirected Kora's question to the whole class. That piece of talk was transcribed within a larger segment, the discussion of the third quiz question, which was represented and analyzed as part of a phase of activity called discussing the quiz questions, which was embedded in the event the class referred to as taking a quiz and discussing the answers. This event occurred during one of the cycles of activity called reading the Canterbury Tales within the course's two semesters of academic activity.

When particular bits of discourse were selected as telling cases, they were transcribed according to a system developed by sociolinguist John Gumperz (1992) and Green and Wallat (1981) and rendered in the work of classroom researchers like the Santa Barbara Classroom Discourse Group. This approach represents strings or segments of talk as interactions between speakers' actions that are meaningfully related (Green \& Wallat, 1981). Each speaking action is transcribed into message units, which are bits of talk (e.g., words and phrases) marked intonationally and identified from contextualization cues (Gumperz, 1992). Message units represent actions in keeping with Bakhtin (1981) and Fairclough's (1993) claim that dialogue should be understood as social action, where every utterance is an action that has meaning and consequence in relation to other utterances. These transcripts were read as maps of meaning-laden actions that were responses to previous meaningful actions or set in motion subsequent actions. Transcribing at the level of the message unit allows observation of collective meaning construction at the level of individual utterance. (For example, Table 5 depicts a classroom conversation in message units whereas Table 4 displays the dialogue in action units.) 


\section{Results}

The three telling cases that follow profile a relationship between individual performance and collective resources during the teaching and learning of the classroom's way of reading. The cases are organized to present an individual learner's emergent reading practices as she comes to understand and then execute performance expectations, some of the classroom's collective discursive resources that supported her emergence, and the teacher's discursive actions during classroom reading discussion that mediated the process. The cases will not tell a complete story of Kora's transformation, nor were they all the resources available to her. Their purpose is to (a) provide a view of what constitutes classroom dialogue supportive of student learning when there exists a wide difference in reading knowledge and student status and (b) foreground the teacher's role as dialogue mediator.

\section{General reader transforms her practice}

Kora's entry into case-making reading practices is observable in the progression of some of her early writing. Analyses of two of her quizzes show her initial performance and a later one. In the first 31 days, eight quizzes were given, seven of which were followed by related class discussions. The quiz and discussion cycle of activity was repeated throughout the entire course and became an expected connective link between individual readings of the class text, whole-class constructed readings, and student essays that ensued.

Kora's first two quizzes each earned an F. The three questions on each quiz were in keeping with the reading practice being established by the class. They called for recall of events in the story and student interpretations. As is observable in the following questions from the second quiz, the questions reinvoked the ways of thinking called for in the class motto and in making a case: Is anything odd happening? (2) And, why (1) and how (3) might two textual events be important? By including the words important (twice) and odd, the questions echoed the class motto.

1. Describe the Finn episode briefly. Why might it be important to the narrative?

2. Explain the role Hrunting plays in Beowulf's battle with Grendel's mother. Anything odd about Hrunting?

3. What is the story regarding Thrith, and how might it be important?

None of Kora's answers to the questions on the second quiz were judged acceptable:
1. The Finn episode is the story of a king named Finn who married the sister of another king. But King Finn was bad and one day unexpectedly he picked up a sword and killed his brother-in-law. There was fight [sic] and Finn won but he lost his son and the dead king lost people too. A relative of the dead king took his throne and wanted revenge for the murder of his kings [sic] men. One day when the time was right he picked up a sword and killed Finn and his men. Taking his wife captive, happily and took treasure too [sic]. It was important because Unther killed one of his kinsmen also. But he was respected. I think he's going to kill Hrothgar.

2. I don't know the answer to this question so instead I'll give you some fashion tip. \#1 never where [sic] black sock with white shoes. Major color clash there Mr. M. Basically that's all. Just remember my tip and you'll go far in life.

3. I could never forget good old Thrith. And I didn't forget it because I didn't read it. I tried really I did but it was 11:00 p.m. and my eyes started to kind of drift shut. I couldn't help it.

In writing the second quiz answers, Kora demonstrated she was in the early stages of defining and solving the problems she had encountered in reading the class text. She had a beginner's engagement with the reasoning process and social practices of reading as expected in this classroom. Kora's answers indicated that she had not read all of the text assigned for homework reading. She had read the Finn episode, but not far enough to have read about Beowulf's battle with Grendel's mother or about Thrith.

In answering the first question, she briefly described the Finn episode as requested. However, her speculation as to the importance of the episode to the narrative was judged by the student teaching assistant as unclear and insufficient. Kora either did not know how the episode might be important to the narrative or was unable to adequately communicate the importance in writing.

Kora's answer to the second question, a fashion tip to the teacher who was wearing dark socks with white shoes the day of the quiz, in its content and register indicated she assumed she was dialoging with him. In this text we can observe Kora's view of her teacher and their relationship. The playful tone of her advice and its critical assessment of her teacher's choice of socks suggested she felt a level of safety and familiarity in her role and relationship with him. Her last line telling him that if he remembers her tip he'll go far in life was ironic. In an interview Kora had proclaimed her high regard for her teacher whom she already considered to have "gone far in life" as an excellent teacher. Her confident voicing of this ironic advice is predicated on her belief that he is a 
successful teacher and that he shares that belief. It acknowledged and affirmed his role of trusted teacher and her role as respectful yet aspiring student.

Kora's third answer enlarged the dimensions of her student role, and it indicated she was grappling with learning how to read longer portions of complicated text. She began with a flip comment about the text tied to her previous comic response, and then she abruptly reversed the tone to an earnest confession: She had not read the text. The answer shifted to a report of her reading activity (she fell asleep while trying to finish her reading) and ended with an excuse as though asking to be forgiven: "I tried really I did...I couldn't help it." Kora's report of her reading indicates that while she knew what was expected and was trying to meet expectations, she recognized she had not yet done so. In Kora's earnest voice we hear a committed, hard-working reader who was making goodfaith efforts to meet her teacher's expectations for reading.

Kora submitted a blank sheet for her third quiz because, again, she had not read the assigned pages as she had come to understand what was expected. In this action we observe that her understanding of expectations still precedes her performance capability. However, for the fourth quiz she completed her readings of the text in a way that demonstrates her understanding of how to read and what to write. At the bottom of the quiz in a note to the researcher she added, "I wrote in my learning log. I wrote four and a half pages front and back. It helped. I actually wrote something down on a quiz." Kora not only wrote something, what she wrote met expanded expectations for quiz writing. She wrote specific allusions to the text and made a case for a conclusion.

Question 1. Describe the Wife of Bath and identify any qualities that might make her seem modern.

Answer 1. (received an OK rating)

The woman from bath was slightly deaf and had five husbands who died. Her figure was normal she wore a flowering mantle to hide her large hips. She was modern in the fact that she married men and then she threw them away. She was learned and [sic]

Question 2. Contrast the Parson, the Friar, and the Monk.

Answer 2. (received a plus rating)

The monk was more like a rich nobleman than a religious leader. He loved to hunt, he dressed in fancy, expensive clothes. The Friar was mellow, but he flirted with pretty girls. He was only in the religious business for the money. He was sort of a swindler. The Parson was the only really religious one, he did it to help people and he hardly ever took money. He was a clerk. The monk, the Friar, and the parson were more like the nobleman, the swindler and the priest.
Question 3. Make a case for one pilgrim being the most evil.

Answer 3. (received a plus rating)

I think that the Friar is the most evil of the pilgrims. He is in a holy profession and instead of using the trust he is given to help people he uses it to swindle money out of poor people. He hears confessions, and gives gifts and the like only because he expects payment. He is a crooked clergyman if I ever saw one.

By the fourth quiz, Kora had learned how to read all the assigned text, to make helpful log notes on her readings, to write in the assertive tone of exposition, and to include textual details in support of her point. Her third answer made a case for her thesis that the Friar is the most evil of the pilgrims. Though the case is brief, it contained three of the elements expected for case making. She stated her thesis in the first line, elaborated on it in the second, and provided textual references as evidence in the third. Her fourth and final line reasserts her thesis.

As suggested by Bakhtin (in Todorov, 1984), these early quizzes may be thought of as both the dialogic medium through which Kora constructed a shift in her identity as a reader and in her understanding of reading, and as a display of that change. She shifted voices from the confessional utterances of a struggling learner to the assertive voice of a confident knower. Her view of reading altered from a narrative reporting to an analysis of oddity and importance. These tranformations represent the state of her understanding of the reading expectations of the classroom and a repositioning of herself as a reader within it. As Gee (1996) theorized, she has taken on a new identity kit by taking on a new way of writing that represents a new way of reading particular to the social and academic demands of this classroom. The quizzes show us Kora's transformed view of reading as a new body of knowledge, procedures, and strategies for getting reading done with her classmates. She has changed, but Kora has changed in relation to the readers around her; her new categories of valuing, of formation, and of evaluation are as much her classmates' as hers. Her sense of herself and what she knows cannot be considered separately from the people and activities in which they are actualized.

\section{What classroom resources were available to Kora and her classmates?}

By taking Kora's repositioned sense of self and of reading as a reference point, in this next section I'll discuss some of the classroom's discourse resources-some of the knowledge, procedures, and strategies related to making-a-case reading. As previously mentioned, explicit direct instruction of making-a-case literacy did not occur. Applying Pinker's distinction (as quoted in Gee, 1996, 
p. 138) between "learning" as a consciously taught, analytic process and "acquisition," which is "a process of acquiring something (usually subconsciously) by exposure to models, a process of trial and error, and practice within social groups, without formal teaching," the making-acase literacy was acquired, rather than learned. From the first day, intellectual framing and problems were posed that set reading conversations in motion. The conversations became chains of opportunities for teaching and learning as single opportunities serendipitously presented themselves, were recognized and taken up by interactants, and were unconsciously guided by the teacher.

During the first few days, the teacher did explicitly teach close reading of text at the level of word to make inferential meanings, establish an intellectual frame using the class motto, and then ask students to make readings of portions of text informed by these approaches. Throughout the remainder of the course, by responding to student accomplishments in the moments they occurred and by modeling, he indirectly engaged students in particular interactions through which they constructed, and thus acquired, aspects of making-a-case literacy. On the classroom floor, individual readings and shared readings of the common literary text were repeatedly talked into being as cases in relation to classroom performance expectations, which were also under construction.

Individual students' written cases for their readings were assessed by peers and the teacher to point out the writer's current case-making proficiency. The quality of student case making and the perceptions of class members as to their peers' capability altered over time as all members of the class became capably socialized at making-a-case practices. Kora's improved performance on the quizzes and her continued transformation as a reader were linked to multiple opportuntities for engaging in discourses within which she was not positioned to feel powerless or at risk. Rather, she could voice her current understanding and build new understandings that she, her teacher, and her classmates valued.

\section{Classroom activity as opportunities for making-a-case reading}

This section will focus on the resources available to Kora as a participant (i.e., as overhearer, speaker, or writer) in the classroom's discussion discourse. Prior analyses of discursive events during class discussions made visible the growth in collective understanding in these first 31 days (Rex, 1997; Rex, Green, \& Dixon,1997; Rex \& McEachen, 1999). These studies described how in their discussions of the text, students had coconstructed a particular sociocultural understanding and proficiency in making-a-case reading that continued to evolve.
Over the first 31 days, classroom discourse events that provided engagement in making-a-case literacy were organized into two domains: events in which reading was the primary focus and those focusing on writing. In the former domain, class members most often negotiated a common reading through class discussion after producing an individual spoken or written text of their homework reading, quiz, or timed writing. In the latter, students moved through the process of writing an essay to make a case for their particular reading. Their first experience was with Beowulf. They discussed their topics (Day 6) and expectations for written performance (Day 7); they presented their topics to the class for discussion (Day 8), read their first drafts to one another (Day 10), and edited one another's final drafts (Day 11). In the former, writing may have served to support, record, or display reading. In the latter, when writing was the primary focus, the reading became the content for its practice. However, both domains of writing when they were read and discussed, which they frequently were, provided opportunities for engaged learning and public indicators of members' evolving capability in case-making reading.

These two types of reading-related events were organized into cycles of activity, in which discrete events took place sequentially over multiple class sessions toward a particular purpose (Green \& Meyer, 1991). The class knew that certain activities would occur and reoccur and what they meant. For example, they understood taking quizzes on the reading would be an ongoing part of the course. Six of the 14 cycles of classroom activity that occurred in the first 31 days engaged in constructing making-a-case reading. These were (a) a reading cycle during which students and the teacher constructed readings of Beowulf during class discussions; (b) a cycle of quiz writing that required students to make unprepared written cases for their prior evening's homework readings of first Beowulf and then Canterbury Tales; (c) an essay cycle during which students developed written essays persuading their readers to accept one reading of Beowulf over another; (d) another reading cycle that continued to call upon students to make public verbal cases for their readings, this time of Canterbury Tales; and (e) a cycle of timed writing wherein students were asked to make a quick and efficient written case for their reading of a tale, and (f) another essay writing cycle about a story in Canterbury Tales, which asked students to evolve through multiple drafts a written case for the efficacy of their individual reading.

Never absent, Kora engaged in all of these cycles, though her early written work indicated her limited understanding of how to make a case. She engaged in side talk with her seatmates during class discussion until she was brought into a discussion by the teacher on the 16th day. 


\section{The classroom's interaction spaces for constructing reading}

These multiple events for constructing and presenting readings took up most of the class time during the first 31 days. Within these events a particular interactional space predominated the teacher-initiated discussion with the class (Heras, 1993). (A listing of all the interactional spaces engaged in by the class members is available in the Appendix.) Frequency and duration analysis of interactional spaces for events over the first 30 days indicated that the most frequent discourse spaces were teacherinitiated and teacher-directed interaction with the class as a group (T-G), teacher-initiated and teacher-directed interaction with a subgroup of students while the class looked on (T-St(s)-G), and student subgroup initiation of interaction that the teacher directed (St(s)-T-G). Of 1,670 instructional minutes in the first 30 days, 1,216 minutes were spent in these configurations. On most occasions in the first week, the teacher initiated, framed, and directed the interactions to either the whole group (T-G) or to a single student or small group of students (T-St(s)-G) while the rest looked on (Larson, 1995). After individuals shared their essay topics with the class (Day 8), on Day 9 students began to initiate interactions with the teacher (St(s)-T-G). As the class looked on, Kora presented her thinly developed topic and then talked with the teacher about how she might develop it further. In addition, other interactional spaces occurred each day; and during the six cycles constructing making-a-case literacy, all the interactional spaces engaged in throughout the year-long class were taken up. For example, with regularity, pairs and groups of students (including Kora) engaged in side talk off the floor of the classroom as a public conversation commenced (St-St and St-Sts). Beginning on the fourth day when students were asked to read their riddles aloud, individual students initiated and directed conversation with members of the whole class in which the teacher participated (St-G).

That the public interactional space was dominated by teacher-to-student discourse attests to the dominant mediational role played by the teacher during the first weeks of the course. Until the 21st day, when for the first time students proposed and made a case for a reading, he directed nearly all public conversations about textual readings. However, as will be apparent in later analyses, this does not mean that the teacher maintained a constant authoritative role in the construction of the readings or in his role as privileged reader. By maintaining particular rules, norms, and practices, which served as maintenance practices, the teacher promoted the emergence of transient practices. The remainder of the results section describes cases of maintenance practices and the transient practices they made possible.
A maintenance discourse structure: A five-part set of classroom teaching and learning practices

Analyses of the organization of class time and discourse indicated that a pattern of five interconnected teaching and learning phases recurred throughout 11 of the 14 cycles of academic activity during the first 30 days of instruction. These may be referred to by the folk terms, or words used by class members, as explaining, modeling, practicing, stamping, and presenting. The redundancy and consistency of this routinized pattern of academic practices provided students with multiple opportunities to coconstruct the rules for academic participation, to engage productively, and to build their capacity for doing academic work. The pattern progressed in the general order represented in the model that follows (see Figure 1). The model is an analytical construction of a typical sequence and does not reflect the lived, day-to-day organization of sequential phases. Within cycles there was considerable variation in the time and order of the phases. Phases might be brief in one cycle and afforded more time in another, as well as shift positions or repeat.

During the explaining phase, the teacher framed an activity in which he wanted students to engage by locating it in relation to something of value the class had already done or would be doing. He described the format and procedure of the activity, explaining its purpose, and providing his expectations for performance. The activity

Figure 1 Pattern of teaching and learning practices

1. Explaining
- The teacher frames the activity by locating it in relation to some-
thing of value the class has already done or will be doing.
- The teacher describes the format and procedure of the activity.
- The teacher explains the purpose of the activity.
- The teacher provides his expectations for performance of the
activity.
2. Modeling
- The teacher provides a range of artifacts to serve as telling cases.
- Class members coconstruct readings of the artifacts to deduce
meaningful traits, qualities, and patterns to guide the creation of
their own artifacts.
3. Practicing
- The teacher leads the students through the practice of some aspect
of the academic project they are working on.
4. Stamping
- The teacher date stamps benchmark artifacts of the activity process
and records them for credit.
5. Presenting
- Students present artifacts of their activity to the class.
-


may have occurred within a single event (e.g., the first reading event of Beowulf), across multiple events within a cycle of activity (e.g., writing the Beowulf essay), or across cycles (e.g., making cases for reading and writing). Sometimes, as during the ballad writing cycle of activity, the teacher began writing the ballad with the students before providing an explanation. Most times, explanation introduced what was to follow, as observed during the first class session when teacher and students constructed the first reading of Beowulf. The teacher induced a definition of inference from a student before coconstructing models with other students, leading the class through practice sessions, and sending them all off to produce a homework artifact of their understanding, which was stamped and presented the next day in class. Though this was an explanation for the kind of reading students would be held accountable for in that specific activity, it was only the first of many contributions to an evolving explanation of reading. For example, on the third day, the teacher used reader response theory to explain reading as a meaning-making activity, which would generate parallel readings, collaborative readings, and misreadings of Beowulf. Then on the fifth day, as previously described, he presented the class motto.

The modeling phase occurred when the teacher modeled the written artifact (which required complicated and rigorous literacy performances) that he expected students to produce. He used both published and student texts (written by students from other classes, and often other years) as models (e.g., essays, ballads, riddles) to provide a range of various capable performances. The models were not meant to be copied but rather were presented as guides for what could be accomplished. He led students through coconstructed readings of the texts to deduce meaningful traits, qualities, and patterns that might guide students in the writing of their own pieces. By forwarding particular types of conversations of published models and student models, the teacher and students constructed ties between the literary texts they had studied, the ones they were currently reading, and those they would write to extend that study.

The teacher coconstructed the ties and extended the models by telling stories of how they came to be written so that literary verse as well as student- and teacher-written verse were presented as arising out of meaningful, real-life, everyday situations. He often talked about the texts in the same language he used to explain his expectations. For example, after the teacher said students should enjoy ballad writing by writing about occasions meaningful to them, he told about a boy from a previous year who, scorned by his prom date (also a class member), wrote his ballad to publicly avenge him- self. Kora wrote a short but successful ballad that demonstrated the naughty public humor of the genre.

By using artifacts written by students from previous years, the teacher made textual links across time, which allowed current students to orient themselves within the student practices and academic expectations of prior years. They came to see themselves as members of a historical progression of GATE English literature students who had gone on to be successful university students. This lent credence and stature to the difficult work they were doing.

In addition to practicing literacies central to writing ballads and riddles, as described earlier, students practiced making cases for their readings of Beowulf or Canterbury Tales, wrote quizzes, and discussed their quiz answers. More time was taken up by the practice phase (the teacher guiding students through some aspect of a literacy they were learning) than any other phase of teaching and learning activity. Consequently, more occasions for the construction of norms for social participation and academic performance were available during this phase than any other.

The stamping phase occurred at the end of events and cycles of activity that produced work the teacher determined worthy of evaluation. Each written piece was stamped with a date on the day it was turned in, which was expected to be the deadline. None of the stamped texts were given letter grades, but rather marked with plus, check, or minus marks to represent whether their performance was respectively excellent, satisfactory, or unsatisfactory. Essays had their own marking system. Preliminary drafts were date stamped to indicate completion by the deadline. Final polished essay drafts were given full credit if they were within the making-a-case performance range considered suitable by the teacher. They were given a grade of $\mathrm{B}$ or lower if they did not achieve that level of performance after revisions. All marks were compiled at the end of a marking period and converted into grades according to a percentage system. While deadlines, unless otherwise negotiated, were fixed and frequent topics of conversation, assessment was regarded as a social practice, and the rubrics for assessment were social constructions representing the current performance range of most of the students. Grades, when earned, became a private topic of conversation between the student and the teacher. Only one student in the class earned a full credit on the first essay, and it was not Kora.

Several methods positioned students to display their work for public analysis and acknowledgment during the presentation phase. Students sat on the teacher's stool in front of the class while the teacher sat in a student's seat. The class applauded the presentations, and in most cases the teacher and some of the students pointed out effec- 
tive elements in the texts. General and GATE students' performance ranges overlapped in their production of the ballads and riddles and came increasingly to overlap in writings associated with the readings. Students could assess where their performance stood in relation to their fellow students', which contributed to the deconstruction of privileged positioning previously exclusive to GATE students.

\section{Maintenance rules governing social participation and academic engagement}

Each explaining, modeling, practicing, stamping, and presenting phase of the academically literate procedures was first introduced and then, with successive applications, reinforced rules for students' social participation and academic engagement. The redundancy of discursive events exercising these rules constructed cultural norms upon which the teacher and students could rely as they made decisions about how to act. Different reading activities across time took on a permanence and solidity as members reinvoked the rules structuring their enactment. Kora and other struggling classmates understood where, when, and how they could enter the conversation and be reasonably assured of how they would be treated.

An example of a particular rule governing social participation and academic engagement is available in the following analysis of an interactional segment during a modeling phase of the ballad cycle of activity (see Table $3)$. In this brief interaction, the teacher and students are observed in the act of poking fun at their own former readings of the classroom text while serving a serious academic purpose.

After a reading of the ballad "Get Up and Bar the Door," the teacher and students coconstructed a list of differences between the poem and Beowulf. The excerpt from that interaction shows a student (St1) offering a difference (line 1), which the teacher acknowledged and confirmed (2). A second student (St2) offered another answer (3), which the teacher also confirmed and then built upon with a question about the language of the text: "Would you say this is a higher or lower level of language?" (4). Students from all over the classroom (5) and the teacher confirmed and contributed additional responses $(6,7,8,9)$. The teacher noted with more specificity that "It's very believable, isn't it? It's a domestic scene." At that point, the third student noted, "Yeah, it's not about religion" (11) and in doing so alluded to the dominant topic, Christianity, of most of the students' essays. The third student had acted upon a classroom social rule: It's perfectly acceptable to make jokes about the kind of work in which the class is engaged. He had made an inside joke, which the teacher and other students recognized (i.e., the class laughed), and the teacher acknowledged (12).
Table 3 Segment from the modeling phase of the ballad cycle (T-G)

\begin{tabular}{ll}
\hline 1. & $\mathrm{St} 1$ \\
2. & $\mathrm{T}$ \\
3. & $\mathrm{St} 2$ \\
4. & $\mathrm{T}$
\end{tabular}

It's funny.

Well, there's humor, isn't there?

The language.

Of course, they both are translations, but the translators made an effort to emulate the level of language. Would you say this is a higher or lower level of language?

\begin{tabular}{|c|c|c|}
\hline 5. & Sts & Lower. \\
\hline 6. & $\mathrm{~T}$ & It's more common, everyday. Yes. \\
\hline & St3 & $\begin{array}{l}\text { It seems like it's more civilized. There's more about life } \\
\text { you can really see. }\end{array}$ \\
\hline & St 4 & More modern. \\
\hline & St3 & Yeah, it's more modern. \\
\hline 10. & $\mathrm{~T}$ & It's very believable, isn't it? It's a domestic scene. \\
\hline 1 & St3 & Yeah, it's not about religion. \\
\hline & $\mathrm{T}$ & No. No Christ imagery. \\
\hline 13. & Sts (laugh) & $\begin{array}{l}\text { [Most of them wrote essays about the Christ imagery in } \\
\text { Beowulf] }\end{array}$ \\
\hline & St3 & (Teasing) The husband could be Christ. \\
\hline & $\mathrm{T}$ & (Playing along) Well, OK, there's a bar on the door. \\
\hline
\end{tabular}

Student and teacher kept the joke going by teasing "The husband could be Christ," (14) and "Well, OK, there's a bar on the door" (15). By stretching the joke to allude to the crucifixion cross (15), the teacher had invoked a complementary rule, that bringing forward related cultural knowledge builds upon initial readings.

This humorous interaction was not a diversion but rather a common feature of teaching and learning practices in this classroom. It demonstrates the ways in which historical, academic, and social texts were interwoven. Not only is the subject matter of ballads funny when compared to Beowulf, discussion of the subject matter can be funny when contrastive allusions across texts reverse normal expectations. This moment of academic and social interchange could not have occurred if prior intertextual references had not occurred and been treated in particular ways (Bloome \& Egan-Robertson, 1993).

Previously constructed rules for social participation allowed students at this point in culture formation to poke fun at prior classroom performances held in common. The third student speaker was not taking a risk, but rather taking up a social opportunity when he made his sardonic allusion. Because this rule was reconstructed and reconfirmed by the class members as socially appropriate, this interaction can be read as displaying a commonly held value and understanding, which implicates the possibility of future opportunities for this social posi- 
tioning to be exercised by classroom members. Data analyses indicate that this was the case. Students repeatedly stepped onto the classroom floor to poke fun at classroom activity. These acts often undercut potentially tense moments and saved face for students whose performances may have been regarded as deficient. Attention was deflected away from the student and toward a new feature of understanding that inspired amusement. Kora was the positive recipient of one of these occasions, when a GATE student used humor to deflect attention away from her misreading. As observed in this instance, the jibing also served to meaningfully reinforce rather than diminish the teacher's academic expectations for student performance.

\section{Transient discourses: How were making-a-case readings and readers constructed over time?}

While some discursive teaching practices served to maintain the stability of rules for social and academic conduct, other discourses provided the means for transformation of understandings, procedures, and relationships. The section that follows provides illustrations of these transient discourses. First, in order to observe a pattern over time of the construction of the discourse culture, eight cases of transient construction of making-a-case literacy are briefly described. Then, two of the eight are closely analyzed to provide a more detailed view of transient discourse in action. The first shows how the teacher talked differently to the class as students became more proficient case makers. The second analysis illustrates how the teacher brought students like Kora, who had not publicly entered the dialogue, into the conversation.

\section{Seeing patterns of readings and readers across dialogues}

Over the first 31 days of class, both GATE and general students emerged in various ways as case makers, representing a gradual transformation of their reading knowledge and of their roles as readers. The gradual, moment-to-moment constructions of transformation are visible in eight interactional segments extracted from classroom reading discussions on Days 1, 2, 4, 7, 16, and 21 (see Rex \& McEachen, 1999, for a more extensive analysis). Across these eight segments we can observe how the teacher talked differently to the class as students became more proficient case makers. The teacher moved the reading practices of the students to increasingly sophisticated levels within the principles established by the motto, and he repositioned power relationships as to whose and which reading counted. On the first day, the teacher led the reading of a class text at the level of word meanings. Modifying the traditional IRE (i.e., Initiation Response Evaluation) pattern (Mehan, 1985), he accepted all student readings in place of his own, to avoid his read- ings being construed as definitive. On the second day, while he was leading the class in a close reading of text, he declined a GATE student's reading strategy of referring to external authority and gave more weight to well-reasoned readings. On the fourth day, the teacher led GATE students in a discussion of quiz answers, affirming but also challenging all student readings as he led them through constructing cases by reasoning from textual evidence. When on the seventh day the teacher directed Kora to bring her question to the floor of the classroom, his actions prompted a conversation that served to establish the importance of questions in constructing readings and cases for readings. Also of importance in that dialogue was the recognition of the power of questioners in relation to knowers and the intellectual capability of general students to eclipse GATE students.

Three separate but related interactions occurred on the 16th day of the class that reinforced the power shifts in what constituted a valid reading and being a successful reader. First, a student challenged the teacher's reading, other students found evidence to support his claim, and the teacher acknowledged their case. That encounter established that (a) students can teach the teacher and the teacher can learn from the students, (b) the teacher's authoritative readings are only as good as the evidence from which they are built, and (c) a reading is a hypothesis until a persuasive case has been made for it. In the second dialogue, when Kora took a Christian analogy literally, the teacher's response supported the belief that all members were responsible for assisting one another and for making the classroom a risk-taking culture. During that interaction, when a few students mocked Kora, the teacher and a GATE student saved face for Kora while reinforcing the understanding that a body of textual knowledge is necessary for reading texts. On Day 16 in the third dialogue, the teacher asked a GATE student to provide knowledge from her life experience to assist a general student in reading the text. The teacher mediated when the GATE student forgot part of the information, and she asked and received assistance from the class.

Finally, an incident on the 21st day of the class demonstrated the extent of collective transformation. During a classroom reading discussion, a number of students took the floor to convince a classmate of the validity of their reading. Although not a direct participant, Kora was involved in this event. For the first time, students made a case for their reading, and the teacher did not initiate or assume direct mediational authority. This event suggests that in acting as teachers for a classmate these students had achieved a particular sociocultural proficiency and ease with making-a-case reading, which was recognized by their peers and their teacher. (See Rex, Green, \& Dixon, 1997, for a full analysis of this event.) 
By looking chronologically across these cases, two patterns emerge: (a) the progression from teacher-led interactions to student-led collaborative case making, and

(b) the building of authority for student readings through the learning of reading actions central to making cases for their readings. Students who had been proficient readers by elaborating upon their teacher's readings, or by providing limited accountability for their own, were expected at this point in the class to construct original, convincing arguments. More importantly for students like Kora, a third pattern emerges that is also reinforced by other ethnographic data. This class was building a particular kind of risk-supportive conversational culture in which GATE students were positioned as learners of the reading approach with valuable knowledge to contribute, and general students were positioned as intellectual contributors in need of particular kinds of reading knowledge.

\section{How did the teacher's actions shift as students became more competent readers?}

In the following microanalysis of an interaction on the 16th day we can observe how the teacher responded when students exhibited emerging understanding of making-a-case reading and challenged his reading from Canterbury Tales. The segment illustrates how students assumed the position of authoritative readers of text to eclipse the teacher's authority. In analyses of discourse segments prior to this event, the teacher's role as ultimate authority over textual readings was always evident. Students looked to him to affirm readings; however, this authority was mediated by other dimensions of his role. He also acted as a coreader who, given the way readings were defined in this classroom as being under continual construction, did not provide final definitive readings. Instead, a responsibility of his role was to question in order to keep readings open. In addition, he handed over his role of teacher to students who took it up to engage in making-a-case practices and to assume authority for their voicings of readings.

The analysis that follows shows how students (pseudonyms are used) challenged the teacher's reading of the text (see Table 4, lines 1-15). The challenge began with the teacher asking a textual question: "So who is this person?" (1). Bobby (BE) and Patricia (PB) responded respectively with "Their guide" (2) and "Their narrator" (3). The teacher confirmed, renamed the character, "Well, he's their host," and then elaborated (4). Ron (RJ) questioned the teacher's reading with "Isn't there another host who is the actual host?" (5). The teacher answered with a qualified negative: "I don't think so" (6), to which multiple student voices were heard challenging his answer (7). The teacher responded by twice reasserting the correctness of his answer (8).
Rather than provide textual evidence to support his reading, the teacher relied upon his authority to empower his point. However, the students, who had come to understand how one is to make a case for a reading in the classroom and how their interpretations have authority if they can be supported with textual evidence, challenged the teacher's reading. Joetta (JM) began by asking the teacher "Would he describe himself as a striking man with bright eyes?" (9), to identify the location in the text of the host the teacher was referring to. The teacher had been reading the text and began to address Joetta and the class by saying "It says" (10). However, he was cut off by Rhonda (RS) who had recollected from her previous reading of the text another reference to support Ron's reading. She referred to the recollected section, "Yeah, and then he says I'm not very xxxx or something" (11). The teacher handed over the role of teacher to Rhonda and her classmates when he next asked "Oh wait, where does it say that?" (12). Rhonda looked for the section of text for him and for the rest of the class whose body language suggested they were following the argument and referring to their texts to find the section. Rhonda guided the search with "Near the end" (13). Patricia found the reference and jumped in to elaborate, adding another textual reference (14). The teacher found the place in the text and encouraged the contribution (15). At this point in the sequence of interactions, the whole class of students was engaged in the attempt to make a case to the teacher to prove the hypothesis the students held in common that there were two hosts in this text, not a single host as he had read. The teacher and students could be said to have exchanged roles.

When the teacher, who had been reading along in the text, said "Ohhhhh" (17), he signaled that he had come to an understanding (see Table 4, lines 16-39). However, Patricia, who had stepped in to add more textual evidence (16), was not willing to relinquish her voice and her public space on the floor. She said "Now wait" (18) and kept her authoritative position. From it, she gave more textual evidence: "After that he gives like a little thing about each person it says right here." She read "And then he says our host" (18). The teacher acknowledged her position and asked for the exact location in the text of her evidence: "Where does he say our host?" (19). Multiple student voices answered the teacher's question (20).

The teacher found the reference and acknowledged the evidence as he read it (29). Patricia continued to question the teacher to forward her claim (30). The teacher jumped in as she was speaking to confirm that her claim had merit given the textual evidence. He articulated the claim the students had been making, that there is more than one host, by identifying the two hosts: 
Table 4 Day 16: Students challenge the teacher's reading

\begin{tabular}{|c|c|c|}
\hline & Teacher & Student(s) \\
\hline 1 & So who is this person? & \\
\hline 2 & & BE: Their guide. \\
\hline 3 & & PB: Their narrator. \\
\hline 4 & $\begin{array}{l}\text { Well, he's their host. He's the host. He is joined by } \\
\text { these, he's in the tavern and these } 29 \text { pilgrims come } \\
\text { and he then sort of is the moderator through this } \\
\text { whole. He goes with them on this pilgrimage. }\end{array}$ & \\
\hline 5 & & RJ: Isn't there another host who is the actual host? \\
\hline 6 & I don't think so. & \\
\hline 7 & & (Multiple student voices respond) \\
\hline 8 & Well he's the host. He's the host. & \\
\hline 9 & [He has been examining the text] & JM: Would he describe himself as a striking man with bright eyes? \\
\hline 10 & It says. & \\
\hline 11 & & RS: Yeah and then he says I'm not very $\mathrm{xxxx}$ or something. \\
\hline 12 & Oh wait. Where does it say that? & \\
\hline 13 & [He looks through the text in response to students] & RS: Near the end. \\
\hline 14 & & $\begin{array}{l}\text { PB: The very last person. Well it would because on page } 34 \text { it says [she reads] } \\
\text { There was a xxxx also known and they were calling him xxxx. }\end{array}$ \\
\hline 15 & Yes. Right. & \\
\hline 16 & & $\begin{array}{l}\text { PB: And then he says [she reads] "Riding and xxxx finally myself." } \\
\text { And he doesn't include the host there, but when he's telling each one he says } \\
\text { our host. }\end{array}$ \\
\hline 17 & Ohhhhh. & \\
\hline 18 & & $\begin{array}{l}\text { Now wait. After that he gives like a little thing about each person it says right } \\
\text { here. } \\
\text { [she reads lines] "And then he says our host." }\end{array}$ \\
\hline 19 & Where does he say our host? & \\
\hline 20 & & (Multiple student voices give page numbers) \\
\hline 21 & [He reads through the text] & BE: Page 41 \\
\hline 22 & & XX: Our host. \\
\hline 23 & & $\begin{array}{l}\text { JM:[ reading] "He was a very striking man our host." } \\
\text { MS: Yeah, } 41 .\end{array}$ \\
\hline 24 & & $\mathrm{XX}: 41$ \\
\hline 25 & & JM: Marshall in a hall. \\
\hline 26 & & \\
\hline 27 & Oh uhh. & BE: Look at 41. \\
\hline 28 & & \\
\hline 29 & OK. He's. OK. Alright. & \\
\hline 30 & & PB: But he's, isn't he talking about himself? \\
\hline 31 & $\begin{array}{l}\text { Yeah I know. I think there's a host at the Tabbard Inn, } \\
\text { and then he is the host. But that is not the person } \\
\text { who goes with them on the trip. }\end{array}$ & It says right there, it says on page 34 ; it says. \\
\hline 32 & & (Multiple student answers) \\
\hline 33 & $\begin{array}{l}\text { Does he go? [He searches the text] Well it does say the } \\
\text { words of the host in between a couple of tales. It says } \\
\text { the words of the host to, you know, a character. } \\
\text { Well, hmmmm. }\end{array}$ & \\
\hline 34 & & (Students talk among themselves) \\
\hline 35 & Well. & XX: Maybe it's a mouse. \\
\hline 36 & & XX: Maybe it's one of the horses. \\
\hline 37 & & \\
\hline 38 & It might be a horse named host. & XX: Yeah. (laughing) \\
\hline 39 & [He continues searching the text] & (continued) \\
\hline
\end{tabular}


Table 4 Day 16: Students challenge the teacher's reading (continued)

\begin{tabular}{lll}
\hline \hline & Teacher & Student(s) \\
\hline $40 \quad \begin{array}{l}\text { OK. No, he went too. So the first person } \\
\text { narrator is not the host, that's true. }\end{array}$ & (Students talk among themselves) \\
42 & BE: Wow you've been reading this for years and you never even xxxx. \\
& $\begin{array}{l}\text { I haven't honestly thought about this for a while. } \\
\text { Well, you know, you know uhm maybe it is Chaucer's } \\
\text { voice because uhm after the Clerk's Tale there's } \\
\text { Chaucer's envoy to the Clerk's Tale; there's the tale } \\
\text { of Sir Topaz who says it's Chaucer's Tale. So maybe } \\
\text { that's, maybe it is Chaucer's voice. I hadn't thought } \\
\text { about that. Alright. }\end{array}$ \\
\end{tabular}

"Yeah I know. I think there's a host at the Tabbard Inn, and then he is the host. But that is not the person who goes with them on the trip" (31). He followed up his articulation with a question, as much to himself as to the students, "Does he go?" (33). His question served to rechallenge the reading, which now he and the students were making. Multiple student voices responded (34). The teacher answered his own question as he skimmed through the text (33) in pursuit of disconfirming textual evidence (39) as students talked among themselves.

By this point in the conversation, the teacher had stepped down from his role as gatekeeper on the floor of the classroom to look for further evidence to either confirm or challenge the claim he had temporarily come to accept given the evidence students had provided. His act was both a temporary but limited confirmation of the students' success in making their case and a challenge to its authority. The teacher had not quite let go and admitted they had succeeded in providing a more convincing reading. He was still looking for the evidence that would convince him, and thus also modeling for them the necessary extent of making a case.

As mentioned previously, in prior class discussions when students' readings were found wanting or were challenged, they were often acknowledged with humor. In this instance, a student stepped onto the floor to make a humorous comment to the teacher to defuse the seriousness of the moment. The student's comment and the teacher's response indicate the gesture was in keeping with the social protocol of the classroom for dealing with competitive moments when an exchange of power was negotiated. The student said, "Maybe it's a mouse" (36). Another student said, "Maybe it's one of the horses" (37). The teacher responded in a light tone, "It might be a horse named host" (38), to which a laughing student responded, "Yeah" (39).
Throughout the interchange, the teacher had continued his search for textual evidence. When he found it (40), he admitted the students' reading was a more authoritative one than his, given the textual evidence (see Table 4, lines 40-43). Students were impressed (42). The teacher immediately incorporated the new reading to form a new hypothesis, "Uhm, maybe it is Chaucer's voice" (43). He gave a reason for it that was tied to the text. Each of these actions followed the first steps in making-a-case thinking, thus demonstrating the way hypotheses about the significances of readings can evolve from reading difficulties. The teacher moved from confusion about an aspect of the text to a hypothesis evolving from "so what" thinking. In saying he had not thought about this topic previously (43), the teacher was signaling that he was constructing this way of thinking in the moment, in keeping with what he expected of his students. The effect of his actions was to implicitly send the message that this kind of thinking is more powerful and more authoritative than any fixed reading he might previously have made. In terms of power relationships, as the role model for teaching in this classroom he indicated that the powerful position is not so much knowing that, but knowing how when knowing that is inadequate (Ryle, 1949).

Students knew how to make a case, and he knew how to build on the understandings that were constructed from the case building to expand to the next level of construction. His reaction to their emergent reading actions reinforced their new level of understanding and took their attention to the next level of hypothesis building.

All of the students who engaged with the teacher on the floor of the classroom during this dialogue were GATE students. Although general students participated in side talk and in the chorus of comments aimed at the teacher, general students had yet to fully emerge as interactional players in the way some GATE students were making use of the public space of the classroom. Although other data 
indicate that most became more active public discussants as the course developed, some never did; they remained throughout the year, like a number of their GATE classmates, mainly side-talking participants in class discussions. For these students, public exchanges provided the purpose, the occasions, and the relevance for their side talk and for other expressions of their literate performance.

How did the teacher's discourse include less emergent readers? Kora enters the classroom conversation

Other general students, like Kora, did become more active participants in public reading discussions as the year went on. This section describes the first time, during a discussion on Day 16, the teacher acted to bring Kora and her question forward to play a substantial part in the public discourse. The analysis (see Table 5) demonstrates how, through the teacher's physical orientation to students and his construction of interactional spaces, he mediated roles and relationships between Kora, who lacked certain kinds of knowledge useful for reading the text, and a GATE student who had that knowledge. He reinforced the role of students' inquiry questions established during earlier interactions, as well as the value and safety of the classroom floor for asking them, and the responsibility of students to assume the role of teacher. Of key importance to general students like Kora is the effect that interactions like this one have on renegotiating former power relationships.

During the class postquiz discussion of Canterbury Tales on Day 16, the teacher overheard Kora, who had

Table 5 Day 16: Teacher redirects Kora's question to group and requests knowledge from another student

\begin{tabular}{|c|c|c|c|}
\hline & Face & Teacher & Students \\
\hline 1 & G & Love conquers all & \\
\hline 2 & G & Isn't that kind of a funny thing? & \\
\hline 3 & & & KM talks to students sitting near her \\
\hline 4 & $\mathrm{KM}$ & Kora Kora & \\
\hline 5 & $\mathrm{KM}$ & Thanks & KM stops talking and looks up at teacher \\
\hline 6 & $\mathrm{KM}$ & Ask us & \\
\hline 7 & KM & What & \\
\hline 8 & & & $\mathrm{KM}$ : What exactly is a rosary bead? \\
\hline 9 & $\mathrm{KM}$ & OK & I looked in the back it says rosary beads are $\mathrm{xxxx}$. \\
\hline 10 & & & XX: Ohhhhh. \\
\hline 11 & & & PB: Rosary beads or rosary? \\
\hline 12 & $\mathrm{KM}$ & If you've seen & \\
\hline 13 & $\mathrm{KM}$ & a beaded necklace with a cross hanging & \\
\hline 14 & $\mathrm{KM}$ & down & \\
\hline 15 & $\mathrm{~PB}$ & And then every & \\
\hline 16 & G & Is it every 10 th bead? & \\
\hline 17 & G & (T looks at students) & (Multiple student answers) \\
\hline 18 & & & XX: Every bead has a prayer. \\
\hline 19 & & & PB: Every bead you say a Hail Mary \\
\hline 20 & & & and every bead between you say an Our Father. \\
\hline 21 & PB & Right & \\
\hline 22 & PB & but how many little beads are there & \\
\hline 23 & $\mathrm{~PB}$ & between the big beads? & \\
\hline 24 & & & PB: There are like eight or something. \\
\hline 25 & $\mathrm{KM}$ & Eight & \\
\hline 26 & $\mathrm{KM}$ & then you say a Hail Mary for every little bead & PB: That's the whole way around \\
\hline 27 & $\mathrm{KM}$ & and Our Father for every big bead. & \\
\hline 28 & $\mathrm{~PB}$ & Then you work & \\
\hline 29 & $\mathrm{KM}$ & You just keep working & You go through every \\
\hline 30 & $\mathrm{KM}$ & you just hold it as you go through and say & \\
\hline 31 & $\mathrm{~PB}$ & Can you say it? & \\
\hline 32 & $\mathrm{~PB}$ & Can you say a Hail Mary for us? & \\
\hline 33 & $\mathrm{~PB}$ & (T watches $\mathrm{PB}$ ) & Hail Mary \\
\hline 34 & & & Hail Mary full of grace the Lord is with thee \\
\hline 35 & & & blessed art thou among women \\
\hline 36 & & & and blessed is the fruit of thy womb \\
\hline 37 & & & holy Mary mother of God pray for us sinners now \\
\hline 38 & & & and in the hour of our death. \\
\hline 39 & $\mathrm{KM}$ & OK that's one Hail Mary. & \\
\hline 40 & G & And then you would say & \\
\hline 41 & & & (Spontaneous student applause) \\
\hline
\end{tabular}


not yet entered any public discussion, asking her neighbor a question about a term used in the text. "What is a rosary?" she whispered. The teacher called out to Kora. "Ask us" (6), he said, directing her to bring the question to the floor of the classroom. The text of the interaction sequence is rendered in message units linked to face direction. This method of transcription makes visible how the teacher shifts orientation within single speaking actions.

Kora (KM) asked her question (8), and another student who had been an active participant in recent classroom discussions, GATE student Patricia (PB), took it up. Patricia recognized the question as the kind of inquiry already established as suitable for reading the text; that is, word meanings were central to textual readings. She asked Kora for a more specific clarification of her question (11). Was it rosary beads or the rosary Kora wanted explained? Patricia's question signaled she was sufficiently knowledgeable about the subject to assume the role of teacher.

The teacher acted to bring Patricia's knowledge forward to address Kora's question. He began in the role of teacher, switched to the role of student and back to teacher. He explained the configuration of the beads, interrupted himself to ask questions of Patricia (15) and the class (16), then acknowledged Patricia's answer, which he had previously interrupted, and followed up quickly with another question (21-23). When Patricia answered, he restated and so confirmed it (25). Patricia, the teacher, and the students in the class believed Patricia had contributed accurate and useful information in response to Kora's question. The teacher had confirmed its accuracy, and the class had spontaneously applauded (39-41). Knowledge in the form of a cultural text had been exchanged. A kind of group learning had occurred; the teacher had provided the opportunity for one student to bring forward from personal memory a cultural text in response to another student's need to know. The question and the answer had been validated with his full authority and with the social authority of the class.

In this segment, the teacher was the interactional gatekeeper and determined whose voice was heard on the classroom floor and when. (Not until making-a-case events on Day 21 did students take up the gatekeeper role.) The teacher brought forward a general student's authentic inquiry and drew a knowledgeable GATE student into the role of teacher. The GATE student, as was appropriate for this classroom, provided knowledge to illuminate textual meanings. Individual voicings served the common purpose of constructing a reading through the common process of questioning the meaning of a word in the text. Kora, Patricia, their classmates, and the teacher acknowledged the usefulness of Kora's question, which served to reposition Kora as a publicly visible member of the reading culture.
The teacher's mediation was key in how the sequence of actions constructed Kora's social membership tied to academic credibility. The segment began with the teacher talking to (facing) the whole group (1-2). Then, for the next eight message units (4-14), he "oriented to" (faced) Kora to bring her into the group space. Kora was afforded teacher attention during the interaction, but not yet the attention of the class. She got their attention when she asked her question, and she was recognized as a social member through Patricia's question (11). The teacher continued to face Kora as he gave her information. His actions were public, which served to hold the floor open for Kora's needs. However, in another sense the interaction served to remove Kora from the rest of her classmates and from Patricia as one of its members. The teacher "reoriented" the interactional space to reconnect his conversation with Kora and with Patricia to his conversation with the whole group (16-17) when he faced Patricia and the group to ask for information: "And then every...is it every 10th bead?" Students responded accordingly, and XX and Patricia answered him by calling out in a teacher-to-whole-group interactional pattern that had already been established. The individual has now become a group member through discourse interaction.

In the next series of interactions (25-40), the teacher moved back and forth between Kora and Patricia, listening to Patricia's contributions and retelling them in elaborated form to Kora and the class. At this point he was the mediator of knowledge, as well as the gatekeeper of discourse space. He was reflecting his authority on each student through his attention, time, and sanctioned interactional space. By initiating engagement, he brought them forward into the group space and provided his affirmation for their question or answer. This step, given the students' interest in ascertaining the teacher-as-evaluator's expectations for what counts in this classroom, was informative for them. Through his actions, the teacher indicated that such questions and knowledge do count, that the general student's voice and inquiry was valid, and that addressing such questions was the responsibility of the rest of the class.

In summary this interactive view of what counted as providing and taking up opportunities for learning academic literacies has presented a complex, dynamic teaching and learning process through a tightly focused conceptual lens. Relearning to read has been observed as an issue involved in acting like a member of a reading culture. This circumscribed view made it possible to describe how the discursive style of this classroom was supportive of students relearning to read and to theorize the important function of orientation. However, it was necessary to table for future analysis the inescapable role of culture (Lee, 2000). This study did not investigate how classroom 
talk (a) was shaped by cultural predispositions, beliefs, and values the students and their teacher brought with them; (b) was reflected in their nationalities, ethnicities, genders, and socioeconomic positions; or (c) was influenced by their individual patterns of migration and access to resources. A study of Kora's, her teacher's, and her classmates' cultural beliefs and everyday practices, what Bourdieu (1977) has called their habitus, would further illuminate the choices these class members made and elaborate the problem of orientation within a more expansive conceptualization of diversity in classroom reading cultures.

\section{Discussion}

The cases illuminate how a general reader like Kora came to act like and take on the identity of a gifted and talented reader by describing reading as a local social and cultural phenomenon. That is, they demonstrate that to read is to be a social actor and to act as a member of a reading culture is to be a reader. In particular, the cases present a way of describing reading and readers as an issue of membership. Individual actions of readers and reading teachers are viewed as relevant in relation to the opportunities for membership they afford. Classroom interactions among classroom members take their meaning from and give meaning to the social and cultural ordering or "membershipness" of the classroom.

This study builds on and is illuminated by a substantial body of research scholarship about the relationship between individual and group actions by sociologists (especially ethnomethodologists and conversation analysts) and anthropologists (mainly cognitive anthropologists and ethnographic semanticists), which focuses on membership categorization analysis (MCA). (For an extensive list of scholars, with explanations of their scholarship, see Hester \& Eglin, 1997, p. 7.) MCA studies the use of membership categories and membership categorization devices as members of groups accomplish naturally occurring, ordinary activities like reading in an English classroom (Hester \& Eglin, 1997). Membership categories are classifications or social types that may be used to describe persons who belong to a group. For example, in this classroom a membership category would be case maker (Sacks, 1974). Membership categories may be interactionally linked together to form classes, collections, or what is referred to in MCA as "membership categorization devices" (MCDs), which come with rules of application (Sacks, 1974, p. 218).

In the English classroom in this study, one MCD or collection was "reader of literature according to the motto." It included, among others, the membership categories of case maker, essay writer, questioner, inference maker, reading-log keeper, quiz taker, knowledge con- tributor, risk taker, fun poker, and face saver. Using MCA, one could say that to act as a motto reader in this classroom was to follow the rules of case making, essay writing, questioning, inference making, and so on.

Hester and Eglin's (1997) contribution to this long line of scholarship is to argue for a view of culture as internal to individual action, which they refer to as culturein-action. By this, Hester and Eglin meant that individual characteristics "are not relevant without special account of particular courses of interaction in which they are involved. Instead, it is identities for the organization/setting/occasion/activity/turn in question that are relevant" (p. 156). That means all categories or collections (i.e., case maker or reading according to the motto) are occasioned in the sense that each has to be recognized as what is meant for that particular occasion. For example, when taking the reading quiz in the early days of class, Kora needed to understand that this "reading according to the motto" occasion meant she was to be a reading-log keeper, as well as a case maker. She was not supposed to be a fun poker or a questioner in these circumstances. Later on as she engaged in class reading discussions, she learned the rules for being a questioner and risk taker. She learned that "a device [for reading] can mean different things and hence can collect different categories on different occasions and in different contexts" (Hester \& Eglin, 1997, p. 18). Furthermore, she had to decide each usage of every category in the collection each time it was invoked by determining what the category meant, which involved deciding what collection the category belonged to for this occasion. Was this reading according to the motto or was this reading to imitate a genre of literature? After this decision, she still had to determine if this was the occasion to be a fun poker or a knowledge contributor and to decide how poking fun or contributing knowledge was supposed to proceed in this situation.

Answerable through the MCA method and the culture-in-action concept is a question that is central to understanding teaching and curricula that support students in remaking themselves as readers: Where are the rules located that Kora had to learn? Hester and Eglin's (1997) theory clarified that construing Kora's achievement of learning a new way of reading as the learning of decontextualized cultural categories and collections of meaning is wrong-headed. Such thinking eliminates agency and oversimplifies the complexity of what is occurring and the challenges involved. The rules are in readers' actions as members of their reading culture. Hester and Eglin explained that it is

not just that members use culture to do things, but that culture is constituted in, and only exists in, action...

this means that the orderliness [i.e., organized routines] of 
cultural resources (categories, devices, and the rest) is constituted in their use rather than pre-existing as a machinery for whatever use members might want to put them to...it is in the use of categories that culture is constituted this time through. It is in their use that the collect-able character of membership categories is constituted and membership categorization devises assembled in situ: membership categorization devices are assembled objects. (p. 20; authors' emphasis)

To summarize the relevance of MCA for thinking about reading as curriculum and as instruction, becoming a reader in a classroom means learning how to do a kind of reading (i.e., membership categorization) that is carried out differently in each local situation. That is, as individual students reason and act practically among the collective, they collect and contribute to understandings of categories of membership, which they can only understand as relevant in the situations within which they are consituting the categories. Therefore, they need to recognize which category is in operation. The recognizability of relevant categories and collections and students' recognition of them are part of and central to the phenomenon of reading. If students cannot recognize how to act "this time," reading and being a reader, or in Kora's case a remade reader are nonexistent. Through recognizability and recognition, students and teachers position themselves or orient to the membershipness of their reading cultures. Orientation is at the center of individual students' reading and reading improvement and of thinking about student access to reading resources.

\section{Implications for reading curriculum and teaching and learning activity}

Dialogic inquiry differs from the conventional monologic method of teaching high school reading units around literary themes, genres, or conventions (Nystrand, Gamoran, Kachur, \& Pendergast, 1997). A dialogic classroom cultivates reading as the interaction of current common understandings of textual passages, of individual representations of textual meanings, and of students' social facility in doing so. Such a classroom applies instructional practices that nurture relationships between individual actions and collective methods for establishing readings. Readers are oriented to texts by invoking a way of thinking and proceeding. On one hand, this inquiry frame requires a membership maintenance device, like the motto in English literature, to hold constant how readers can voice their readings. The device acts as a set of principles for understanding which readings are permissible. It determines the range of acceptable divergent readings and how they can be brought forward as content for teaching and learning. With principles toward which to orient, reader roles (like risk taker, questioner, and face saver) become available to students, allowing them to try out readings and ways of being a reader.

On the other hand, the inquiry frame and the products that emerged from it as speech or literary genres (e.g., discussions, quizzes, and essays) (Bakhtin, 1986) are also membership devices that serve transient purposes. In an inquiry frame, genres serve the more dominant purpose of articulating credible and significant in-the-making readings. Each writing is an attempt to exercise the current state of reading knowledge, and each attempt produces a variation of the genre. Genres as transient discourses, made for and relevant to unique occasions, become living discursive frames that evolve across time (Goffman, 1974). This transient evolution of genres exists within a collective understanding of what makes up the range of rhetorical features of each genre and how that range is configured. This common understanding does not come from direct teaching; rather, it emerges from ongoing class conversations about expectations and evaluations of texts in which students are invested.

Relationships between expectation and evaluation play an important role in the evolutionary transience of what constitutes reading; the two are concurrently evolving contexts for each other (Erickson \& Schultz, 1981). Reading expectations contextualize the conduct of evaluative conversations, and reading evaluations serve as contexts for what discussions of reading would be expected next. We observed this dynamic occurring during the discussion of how many hosts existed in the Canterbury Tales. The teacher's responses to students' evaluatory actions shifted expectations to another level of hypothesis building as the teacher attempted to construct an evidenced reading that would suit current collective evaluative practices. As speakers within a dialogic relationship draw from one context they construct another to accommodate other transient discourses and their genres of literate performance.

This view of constantly evolving discursive contexts and genres resists efforts to depict content as fixed, learning as acquisitive, and interactional practices as structural constants. This view forwards reading curriculum as dialogic activities rich with member discussions of value, purpose, and goals, which construct local models rather than follow received models. Multiple, redundant occasions for practice are mutable, context-specific, and collectively arbitrated. Rules for reading are made to be reformulated, and routines are the patterned traces that mark where successful readers have made their way.

\section{Implications for teachers}

Teachers' actions in supporting students' emergent understanding of these distinctions are crucial. The approach and design of the curricular elements originate 
with teachers. They shape reading as inquiry by foregrounding students' questions and knowledge, building on them, and moving interactions along so that student questions and knowledge are the basis and the motivation for reading. To do so, they conceive the orienting devices and initiate and facilitate dialogues about expectations and evaluation, by constantly assessing what current social and academic conditions call for. They set in motion and maintain a way of being a literate reader by mediating who can speak and act in what ways, when, and how. As the privileged readers with whom students have to build their own authority, teachers must assume the learner role to open interactions for students to step into teaching roles, while diffusing inequitable power relationships and strengthening participation of less emergent readers. This task involves building rigorous expectations for performance while decreasing student anxieties about how they can accomplish them. For dialogic reading inquiry to work, teachers need to help students participate in determining what is negotiable and what is not and when practices are mutable and when they are not. Such distinctions require orienting discourses to sustain individual learning and maintain group evolution. This study provides only a peek at the complexities of the teacher's role and of the challenges students face. However, it confirms that teachers can provide curriculum and pedagogy that orient students and that students can read those features and take successful action. It forwards the social and cultural dimensions of reading and of being a reader, because to overlook them is to ignore why in too many classrooms too few students have remade themselves as readers.

\section{REFERENCES}

ALTON-LEE, A., \& NUTHALL, G. (1992). Children's learning in classrooms: Challenges to developing a methodology to explain "opportunity to learn." Journal of Classroom Interaction, 27(2), 1-7.

BAKER, C.D. (1991). Literacy practices and social relations in classroom reading events. In C. Baker \& A. Luke (Eds.), Towards a critical sociology of reading pedagogy, (pp. 161-190). Philadelphia: John Benjamins.

BAKER, C.D., \& LUKE, A. (Eds.). (1991). Towards a critical sociology of reading pedagogy. Philadelphia: John Benjamins.

BAKHTIN, M.M. (1981). The dialogic imagination: Four essays by M.M. Bakhtin. (M. Holquist, Ed. C. Emerson \& M. Holquist, Trans.). Austin, TX University of Texas Press.

BAKHTIN, M.M. (1986). Speech genres and other late essays. Austin, TX: University of Texas Press.

BLOOME, D. (1989). Beyond access: An ethnographic study of reading and writing in a seventh grade classroom. In D. Bloome (Ed.), Classrooms and literacy (pp. 53-106). Norwood, NJ: Ablex.

BLOOME, D., \& BAILEY, F. (1992). Studying language through events, particularity, intertextuality. In R. Beach, J. Green, M. Kamil, \& T. Shanahan (Eds.), Multidisciplinary perspectives on literacy research (pp. 181-210). Urbana, IL: National Council of Teachers of English.

BLOOME, D., \& EGAN-ROBERTSON, A. (1993). The social construction of intertextuality in classroom reading and writing lessons. Reading Research Quarterly, 28, 305-333.

BOURDIEU, P. (1977). Outline of a theory of practice. Cambridge, England: Cambridge University Press.
Ablex.

COGHILL, N. (1977). Canterbury Tales. (Trans. into modern English).

Harmondsworth, Middlesex, England: Penguin.

COOK-GUMPERZ, J., \& GUMPERZ, J. (1992). Changing views of language in education: The implications for literacy research. In R. Beach, J.L. Green, M. Kamil, \& T. Shanahan (Eds.), Multidisciplinaryperspectives on literacy research (pp. 151-179). Urbana, IL: National Council of Teachers of English. EDWARDS, D., \& MERCER, N. (1987). Common knowledge: The development of understanding in the classroom. New York: Falmer Press.

ERICKSON, F. (1977). Some approaches to inquiry in school/community ethnography. Anthropology and Education Quarterly, 8(3), 58-69.

ERICKSON, F. (1986). Qualitative methods in research on teaching. In M. Wittrock (Ed.), Handbook of research on teaching (3rd ed., pp.119-161). New York: Macmillan.

ERICKSON, F., \& SCHULTZ, J. (1981). When is context? Some issues and methods in the analysis of social competence. In J.L. Green \& C. Wallat (Eds.), Ethnography and language in educational settings (pp.147-160). Norwood, NJ: Ablex.

FAIRCLOUGH, N. (1989). Language and power. New York: Longman. FAIRCLOUGH, N. (1993). Critical discourse analysis and the marketization of public discourse: The universities. Discourse and Society, 4, 133-168.

GEE, J. (1996). Social linguistics and literacies: Ideology in discourses. London: Taylor \& Francis.

GEERTZ, C. (1973). The interpretation of cultures. New York: Basic Books. GLASER, B.G., \& STRAUSS, A.L. (1967). The discovery of grounded theory: Strategies for qualitative research. Chicago: Aldine.

GOFFMAN, E. (1974). Frame analysis. New York: Harper \& Row.

GOODENOUGH, W.H. (1981). Culture, language, and society. Menlo Park,

$C A$ : Cummings.

GREEN, J.L., FRANQUIZ, M., \& DIXON, C. (1997). The myth of the objective transcript. TESOL Quarterly, 31, 172-176.

GREEN, J.L., \& HARKER, J.O. (1982). Gaining access to learning: Conversational, social and cognitive demands of group participation. In L.C. Wilkinson (Ed.), Communicating in the classroom (pp. 183-221). New York: Academic Press.

GREEN, J.L., \& MEYER, L.A. (1991). The embeddedness of reading in classroom life: Reading as a situated process. In C. Baker \& A. Luke (Eds.) Towards a critical sociology of reading pedagogy (pp. 141-160). Philadelphia: John Benjamins.

GREEN, J.L., \& WALLAT, C. (1981). Mapping instructional conversationsA sociolinguistic ethnography. In J.L. Green \& C. Wallat (Eds.), Ethnography and language in educational settings. (pp. 161-205). Norwood, NJ: Ablex.

GUMPERZ, J. (1992). Contextualization and understanding. In A. Duranti \& C. Goodwin (Eds.), Rethinking context (pp. 229-252). New York: Cambridge University Press.

HEAP, J. (1991). A situated perspective on what counts as reading. In C. Baker \& A. Luke (Eds.), Towards a critical sociology of reading pedagogy (pp. 103-139). Philadelphia: John Benjamins.

HERAS, A. (1993). The construction of understanding in a sixth-grade bilingual classroom. Linguistics and Education, 5 (3/4), 275-300. HESTER, S., \& EGLIN, P. (Eds.). (1997). Culture in action. Lanham, MD: University Press of America. HICKS, D. (1995). Discourse, learning and teaching. In M. Apple (Ed.), Review of research in education (pp. 49-95). Washington DC: American Educational Research Association.

HICKS, D. (Ed.). (1996). Discourse, learning and schooling. New York: Cambridge University Press.

HYMES, D. (1972). Introduction. Functions of language in the classroom. In C. Cazden, V. John, \& D. Hymes (Ed.), Functions of language in the classroom (pp. xi-Ivii). Prospect Heights, IL: Waveland Press.

IVANIC, R. (1994). I is for interpersonal: Discoursal construction of writer identities and the teaching of writing. Linguistics and Education, 6, 3-1. JOHN-STEINER, V., \& MAHN, H. (1996). Sociocultural approaches to learning and development: A Vygotskian framework. Educational Psychologist, 31, 191-206.

JOHN-STEINER, V., PANOFSKY, C.P., \& SMITH, L.W. (Eds.). (1994). Sociocultural approaches to language and literacy: An interactionist perspective. Cambridge, England: Cambridge University Press. KANTOR, R., GREEN, J.L., BRADLEY, M., \& LIN, L. (1992). The construc- 
tion of schooled discourse repertoires: An interactional sociolinguistic perspective on learning to talk in preschool. Linguistics and Education, 4, 131-172.

LANKSHEAR, C., \& MCLAREN, P. (1993). Critical literacy: Politics, praxis, and the postmodern. Albany, NY: State University of New York Press.

LARSON, J. (1995). Talk matters: The role of pivot in the distribution of literacy knowledge among novice writers. Linguistics and Education, 7, 277-302.

LEE, C. (2000). Understanding in the most fundamental way. English

Education, 32, 308-312

LIN, L. (1993). Language of and in the classroom: Constructing the patterns of social life. Linguistics and Education, 5 (3/4), 367-410.

MCHOUL, A. (1991). readingS. In C. Baker \& A. Luke (Eds.), Towards a critical sociology of reading pedagogy (pp. 191-210). Philadelphia: John Benjamins.

MEHAN, H. (1985). The structure of classroom discourse. In T. Van Dijk (Ed.), Handbook of discourse analysis: Discourse and dialogue, Vol. 3 (pp. 119-131). San Diego, CA: Academic Press.

MITCHELL, J.C. (1983). Case and situation analysis. Sociological Review, $31,187-211$

MITCHELL, J.C. (1984). Typicality and the case study. In R.F. Ellen (Ed.), Ethnographic research: A guide to general conduct (pp. 238-241). New York: Academic Press.

NYSTRAND, M., GAMORAN, A., KACHUR, R., \& PENDERGAST, C. (1997). Opening dialogue. New York: Teachers College Press.

OAKES, J. (1985). Keeping track: How schools structure inequality. New Haven, CT: Yale University Press.

OCHS, E. (1979). Transcription as theory. In E. Ochs \& B. Schieffelin (Eds.), Developmental pragmatics (pp. 43-72). New York: Academic Press.

PRENTISS, T. (1998). Teachers and students mutually influencing each other's literacy practices: A focus on the student's role. In D. Alvermann, K. Hinchman, D. Moore, S. Phelps, \& D. Waff (Eds.), Reconceptualizing the literacies in adolescents'lives (pp. 103-128). Mahwah, NJ: Erlbaum.

PUTNEY, L.G., GREEN, J.L., DIXON, C., DURAN, R., \& YEAGER, B. (2000). Consequential progressions: Exploring collective-individualdevelopment in a bilingual classroom. In P. Smagorinsky \& C. Lee (Eds.), Constructing meaning through collaborative inquiry: Vygotskian perspectives on literacy research (pp. 86-126). New York: Cambridge University Press.

RAFFEL, B. (1963). Beowulf. (A new translation). New York: Penguin.

REX, L.A. (1994). A social view of composing from insiders' perspectives: The roles and relationships of teachers and students. 43rd yearbook of the National Reading Conference (pp. 560-571). Chicago: National Reading Conference.

REX, L.A. (1997). Making a case: A study of the classroom construction of academic literacy. Unpublished doctoral dissertation, University of California, Santa Barbara.

REX, L.A., GREEN, J.L., \& DIXON, C. (1997). Making a case from evidence: Constructing opportunities for learning academic literacy practices. Interpretations, 30 (2), 78-104.

REX, L.A., \& MCEACHEN, D. (1999). If anything is odd, inappropriate, confusing or boring, it's probably important: The emergence of inclusive academic literacy through English classroom discussion practices. Research in the Teaching of English, 34, 66-130.

RYLE, G. (1949). The concept of mind. London: Hutchinson.

SACKS, H. (1974). On the analysability of stories by children. In R. Turner (Ed.), Ethnomethodology: Selected readings (pp. 216-232). Harmondsworth, Middlesex, England: Penguin.

SANTA BARBARA CLASSROOM DISCOURSE GROUP. (1992a).

Constructing literacy in classrooms: Literate action as social accomplishment. In H.H. Marshall (Ed.), Redefining student learning (pp. 119-150). Norwood, NJ: Ablex.

SANTA BARBARA CLASSROOM DISCOURSE GROUP. (1992b). Do you see what we see? The referential and intertextual nature of classroom life. Journal of Classroom Interaction, 27(1), 29-36.

SPRADLEY, J.P. (1979). The ethnographic interview. New York: Holt, Rinehart \& Winston.

SPRADLEY, J.P. (1980). Participant observation. New York: Holt, Rinehart $\&$ Winston

TODOROV, T. (1984). Mikhail Bakhtin, The dialogic principle. Minneapolis, MN: University of Minnesota Press.

TUYAY, S., JENNINGS, L., \& DIXON, C. (1995). Classroom discourse and opportunities to learn: An ethnographic study of knowledge construction in a bilingual third grade classroom. Discourse Processes, 19 (1), 75-110.

WEADE, R. (1992). Locating learning in the times and spaces of teaching. In H.H. Marshall (Ed.), Redefining student learning (pp. 87-118). Norwood, NJ: Ablex.

WELLS, G., \& CHANG-WELLS, G.L. (1992). Constructing knowledge together. Portsmouth, $\mathrm{NH}$ : Heinemann.

WERTSCH, J. (1991). Voices of the mind: A sociocultural approach to mediated action. Cambridge, MA: Harvard University Press.

ZAHARLICK, A., \& GREEN, J.L. (1991). Ethnographic research. In J. Jensen, J. Flood, D. Lapp, \& J.R. Squire (Eds.), Handbook of research on teaching the English language arts (pp. 205-225). New York: Macmillan.

Received February 24, 2000

Revision received August 16, 2000 Accepted September 12, 2000 
APPENDIX

Types of interactional spaces

T-G

T-St

T-St(s)-G

St(s)-T-G

T-Sts

St-St

St-Sts

St-G

Sts-G
Teacher interacts with whole class as a group. Discourse occurs on the public floor of the classroom. $\mathrm{T}$ initiates and directs interaction.

Teacher and single student interact in side conversation not in public space, though it may be overheard by others. Interaction can be either student or teacher initiated and directed.

Teacher and single student or group of students interact on public floor of the classroom as though the student represented all students. Teacher initiated and directed.

Student or students interact with teacher on public floor of classroom. Student initiates; teacher directs.

Teacher and a subgroup of students interact off the public floor of the classroom, though they may be overheard by others. Can be either student or teacher initiated and directed.

Student interacts with another student off the public floor. Once initiated, direction can be interchangeable.

Student interacts with subgroup of students off the public floor. Student initiates (sometimes at the request of another) and directs.

Student interacts with whole class on public floor of classroom. Student initiates (sometimes at teacher's request) and directs.

Two or more students in a subgroup interact with whole class. Students initiate (usually at teacher request) and direct. 